\title{
New insights on stratigraphy and sedimentology of the Oncala Group (eastern Cameros Basin): implications for the paleogeographic reconstruction of NE Iberia at Berriasian times
}

\author{
Nuevas aportaciones sobre la estratigrafía y sedimentología del Grupo Oncala \\ (Cuenca de Cameros oriental): implicaciones para la reconstrucción paleogeográfica \\ del NE de Iberia durante el Berriasiense
}

\author{
I.E. Quijada ${ }^{1,2} *$, P. Suarez-Gonzalez ${ }^{1,2}$, M.I. Benito ${ }^{1,2}$, R. Mas ${ }^{1,2}$ \\ ${ }^{1}$ Departamento de Estratigrafía, Fac. Ciencias Geológicas, Universidad Complutense de Madrid, 28040 Madrid, Spain \\ 2.Instituto de Geociencias IGEO (CSIC, UCM), C/ José Antonio Novais 12, 28040 Madrid, Spain \\ equijada@geo.ucm.es; pablosuarez@geo.ucm.es; maribel@geo.ucm.es; ramonmas@geo.ucm.es \\ *corresponding author
}

Received: 04/05/2013 / Accepted: 02/08/2013

\begin{abstract}
The Berriasian Oncala Group of the eastern Cameros Basin is a key element for the paleogeographic reconstruction of NE Iberia during this period of time, due to its intermediate position between the Basque-Cantabrian, southern Iberian, and Pyrenean Basins. The Oncala Group, which comprises up to $2500 \mathrm{~m}$ of sediments, consists of siliciclastic deposits in western areas of the basin, which pass gradually eastwards and upwards to carbonate-evaporitic deposits. The siliciclastic deposits consist of an alternation of laterally extensive laminae of siliciclastic mudstone and sandstone, and meander loop bodies. The carbonate deposits are made up of an alternation of laminae of carbonate mudstone and pseudomorphs after gypsum, interbedded with shales and carbonate breccias. These deposits had been traditionally interpreted as formed in fluvial and alluvial systems, and laterally related lakes, but recent and new sedimentological data discussed in this paper suggest that they were deposited in broad, siliciclastic tidal flats, laterally associated with a fluvial system to the west, and with shallow, coastal, carbonate-sulphate water bodies to the east. The development of these coastal environments in the Oncala Group indicates that a wide, shallow, coastal embayment was developed in the eastern Cameros Basin during the Berriasian. This new paleoenvironmental interpretation makes necessary a revision of the paleogeographic reconstruction of this area of Iberia during the Berriasian because it implies that the connection of the Cameros Basin with marine areas was much more important than previously considered.

The presence of very similar facies associations in the Basque-Cantabrian Basin, which include siliciclastic tidal and lagoonal deposits in the western areas, and evaporites and carbonates of restricted marine environments in the eastern areas, the similar sulphur isotope compositions of the sulphates of the Basque-Cantabrian and Cameros Basins, and the similar vertical evolution of the Berriasian deposits of both basins, suggest that the Cameros Basin was connected with marine and transitional areas of the Basque-Cantabrian Basin during Berriasian times. Nevertheless, a connection with the southern Iberian Basins, which also contain siliciclastic and carbonate tidal deposits, cannot be excluded.
\end{abstract}

Keywords: Oncala Group, Lower Cretaceous, Cameros Basin, Spain, tidal deposits, shallow laminated carbonate-sulphate deposits 


\section{Resumen}

El Grupo Oncala de edad berriasiense de la Cuenca de Cameros oriental es una pieza clave en la reconstrucción paleogeográfica del NE de Iberia durante este período debido a su posición intermedia entre las Cuencas Vasco-Cantábrica, Ibéricas meridionales y Pirenaica. El Grupo Oncala, que comprende hasta $2500 \mathrm{~m}$ de espesor, está formado por depósitos siliciclásticos en las zonas occidentales de la cuenca que pasan gradualmente hacia el Este y hacia techo a depósitos carbonático-evaporíticos. Los depósitos siliciclásticos están compuestos por una alternancia de láminas lateralmente continuas de lutita y arenisca y cuerpos de lóbulos de meandro. Los depósitos carbonático-evaporíticos están formados por una alternancia de láminas de carbonato mudstone y de pseudomorfos de yeso, intercalada con lutitas y brechas carbonáticas. Estos depósitos se interpretaban tradicionalmente como formados en sistemas fluviales y aluviales lateralmente relacionados con lagos pero datos sedimentológicos recientes y nuevos que se discuten en este artículo sugieren que fueron depositados en extensas llanuras de marea siliciclásticas asociadas lateralmente con un sistema fluvial hacia el Oeste y con cuerpos de agua costeros de poca profundidad y de composición carbonática-sulfática hacia el Este. El desarrollo de estos ambientes costeros en el Grupo Oncala indica que durante el Berriasiense se desarrolló una amplia bahía somera en la Cuenca de Cameros oriental. Esta nueva interpretación paleoambiental obliga a revisar la reconstrucción paleogeográfica de esta área de Iberia durante el Berriasiense puesto que evidencia que la conexión de la Cuenca de Cameros con áreas marinas era mucho más importante de lo que se consideraba hasta ahora.

La presencia de asociaciones de facies muy similares en la Cuenca Vasco-Cantábrica, que incluyen depósitos siliciclásticos mareales y lagunares en la zona occidental y evaporitas y carbonatos formados en ambientes marinos restringidos en la zona oriental, la similitud de las composiciones isotópicas del azufre de los sulfatos en la Cuenca Vasco-Cantábrica y en la Cuenca de Cameros y la semejanza en la evolución vertical de los depósitos berriasienses de ambas cuencas sugieren que la bahía desarrollada en la Cuenca de Cameros durante el Berriasiense estaba conectada a las zonas marinas y transicionales de la Cuenca Vasco-Cantábrica. Sin embargo, la conexión con las cuencas ibéricas meridionales, que también contienen depósitos mareales siliciclásticos y carbonáticos, no puede ser descartada.

Palabras clave: Grupo Oncala, Cretácico inferior, Cuenca de Cameros, España, depósitos mareales, depósitos carbonático-sulfáticos laminados someros

\section{Introduction}

Berriasian successions in the Basque-Cantabrian, Iberian, and Pyrenean Basins include continental, coastal, and open marine facies. Prior paleogeographic reconstructions of NE Iberia for Berriasian times placed a northern shoreline in the southern margin of the Basque-Cantabrian Basin, and a southern shoreline in the southeasternmost area of the Iberian Basin (Salas et al., 2001; Aurell et al., 2003; Mas et al., 2004; and references therein). The Cameros Basin, which occupied an intermediate position between these areas, has been traditionally interpreted as a continental basin with few sporadic marine incursions (e.g. Mas et al., 1993; Mas et al., 2004). Specifically, the Berriasian Oncala Group of the Cameros Basin has been previously interpreted as developed in an endorheic playa-lake system, which consisted of continental sandy-muddy flats passing eastwards to saline lakes, in the lower part, and as deposits of deep carbonate lakes laterally related with fluvial deposits in the upper part (Gómez-Fernández, 1992; Gómez-Fernández and Meléndez, 1994a; Meléndez and Gómez-Fernández, 2000). However, more recent studies on the Berriasian succession of the Cameros Basin indicate that siliciclastic tidal flats and coastal, shallow, carbonate-sulphate water bodies (Quijada et al., 2010b; 2013; 2014) were developed in the basin; an interpretation that implies signifi- cant changes for the paleogeographic reconstructions of NE Iberia at Berriasian times.

In order to address the paleogeographic implications of these new data about the Oncala Group (Berriasian in age), a stratigraphical and sedimentological analysis is performed in this study to interpret the depositional systems developed in the Cameros Basin at Berriasian times, the vertical and lateral facies evolution, and the paleogeographic reconstruction of the basin. The new information about the Oncala Group is compared with published data of adjacent basins (Basque-Cantabrian and southern Iberian Basins) to establish possible connections of the Cameros Basin with marine waters, and to revise the paleogeographic reconstructions of NE Iberia at Berriasian times.

\section{Geological setting}

As a result of the opening of the North Atlantic Ocean, an intraplate rifting took place in Iberia from the late Jurassic to the Lower Cretaceous (e.g., Mas and Salas, 2002; Mas et al., 2004), and a series of extensional basins were developed in Iberia, which include the Iberian Mesozoic Rift System, the Basque-Cantabrian Basin, and the Pyrenean Basin (Fig. 1). The Cameros Basin was the northwesternmost basin of the Iberian Mesozoic Rift System (Mas et al., 1993; Guimerà et al., 1995), and re- 


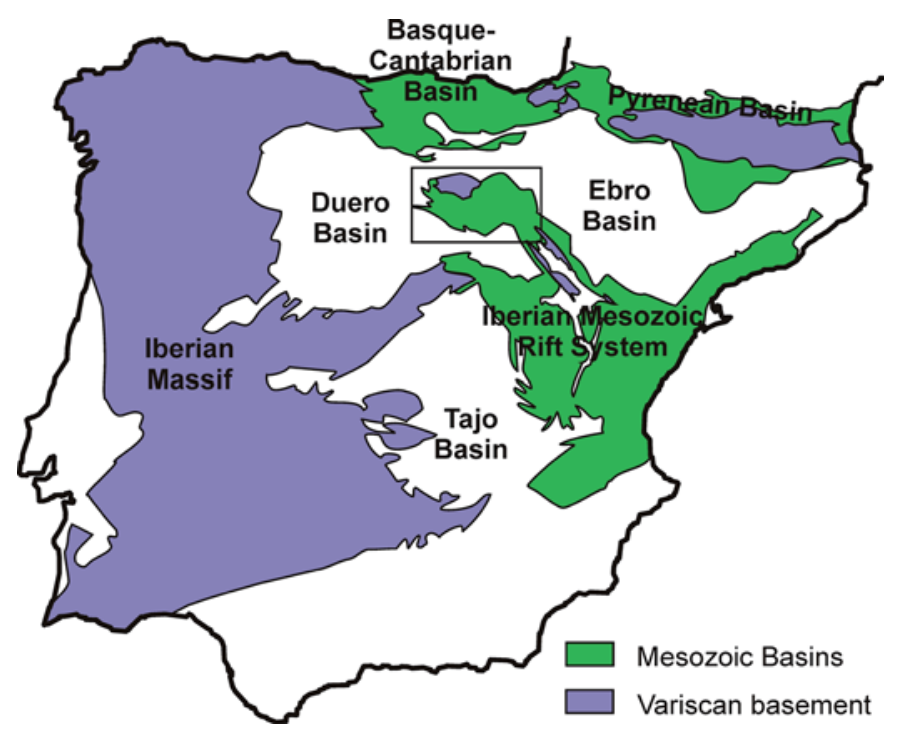

Fig. 1.- Mesozoic basins of the Iberian Peninsula. The rectangle marks the location of the Cameros Basin, and the area shown in figure $3 \mathrm{~A}$.

Fig. 1.- Cuencas Mesozoicas de la Península Ibérica. El rectángulo indica la localización de la Cuenca de Cameros y el área mostrada en la figura $3 \mathrm{~A}$.

corded the highest subsidence and accumulation rates of this system, with more than $6000 \mathrm{~m}$ of vertical thickness of sediments from the Tithonian to the early Albian (Mas et al., 1993; 2002; 2011; Arribas et al., 2003). The infill of the basin corresponds to a large cycle or super-sequence, divided in eight depositional sequences (Fig. 2) bounded by stratigraphic unconformities (Mas et al., 1993; 2002; Arribas et al., 2003). These depositional sequences consist of continental and transitional deposits (Mas et al., 1993; 2002; Quijada et al., 2010b; 2014; Suarez-Gonzalez et al., 2010; 2014).

The Oncala Group, which is the aim of this study, corresponds to the third depositional sequence of the basin (Fig. 2), and was deposited in the eastern sector of the Cameros Basin (Mas et al., 1993; Gómez-Fernández and Meléndez, 1994b), which limits to the West with the Demanda Range (Fig. 3A). Based on data of charophyte and ostracod assemblages, its age is considered as Berriasian (Salomon, 1982a; Schudack and Schudack, 2009). The Oncala Group overlies the Tera Group (Fig. 2), which corresponds to the first and second depositional sequences, and is overlain by the Urbión Group, which corresponds to fourth to seventh depositional sequences (Mas et al., 1993; 2002; Gómez-Fernández and Meléndez, 1994b). The Oncala Group is one of the thickest units of the Cameros Basin comprising up to $2500 \mathrm{~m}$ of sediments in depocentral areas of the basin, and contains both siliciclastic and carbonate-evaporitic deposits, which are laterally related. Western areas contain mostly siliciclastic deposits, and change gradually to carbonates and evaporites to the East (Fig. 3B). Various sedimentologi- cal interpretations of these deposits have been given by different authors. Salomon (1982a) and Guiraud (1983) interpreted western siliciclastic deposits as developed in fluvial systems, and eastern carbonate-evaporitic deposits as formed in sabkhas. Gómez-Fernández (1992) and Meléndez and Gómez-Fernández (2000) proposed that the lower sediments of the Oncala Group were deposited in a continental playa-lake system with sandy-muddy flats in western areas and saline lakes in eastern areas, while the upper sediments were deposited in deep carbonate lakes passing to fluvial systems westwards. Recent stud-

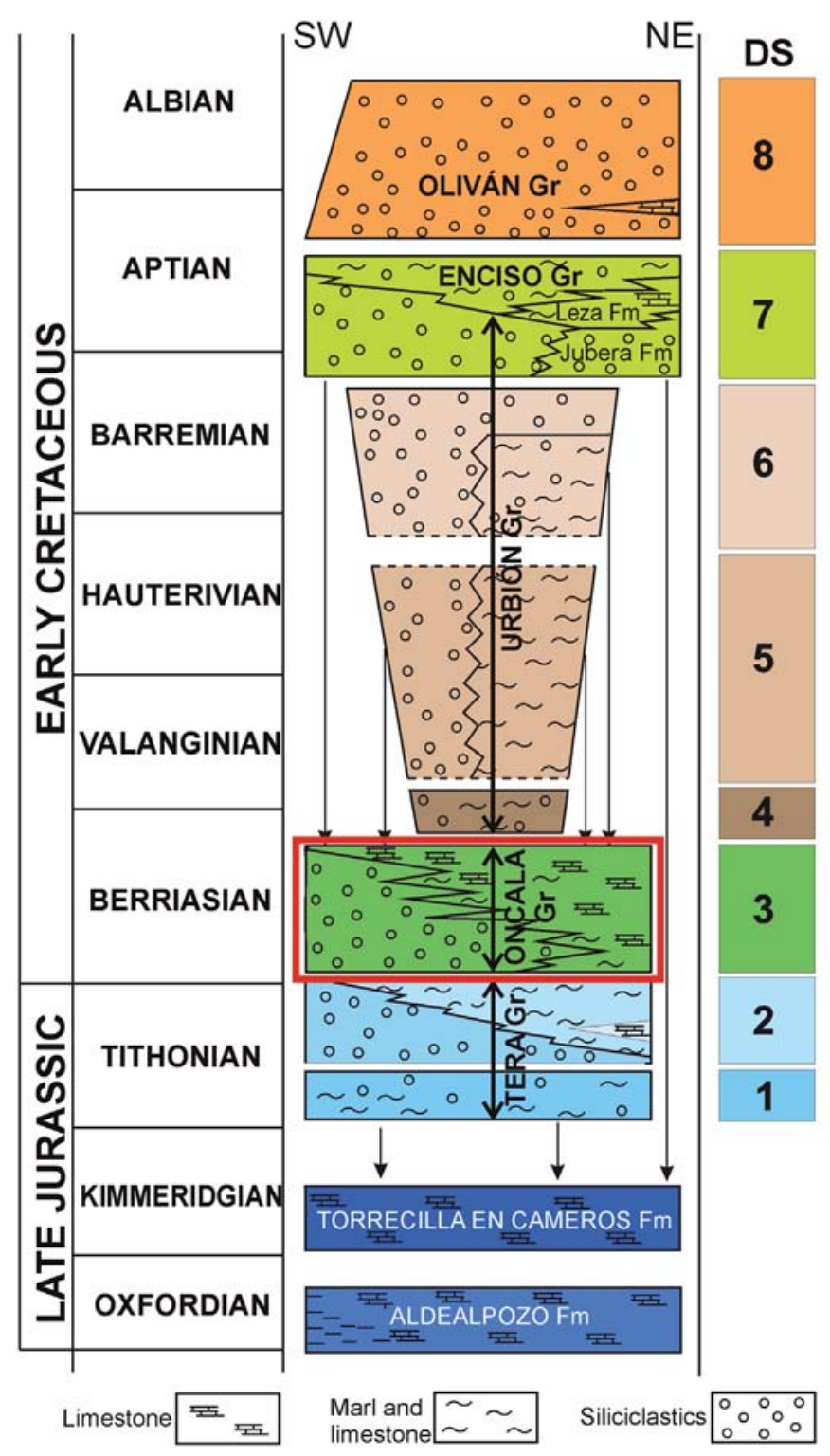

Fig. 2.- Stratigraphic framework and depositional sequences (DS) filling the eastern Cameros Basin. The focus of this study, the Oncala Group, is highlighted with a red rectangle. Modified from Mas et al. (2004). "Gr" = group, "Fm" = formation.

Fig. 2.- Cuadro estratigráfico y secuencias deposicionales (DS) de relleno de la Cuenca de Cameros oriental. El objetivo de este estudio, el Grupo Oncala, está resaltado con un rectángulo rojo. Modificado de Mas et al. (2004). "Gr" = grupo, "Fm" = formación. 


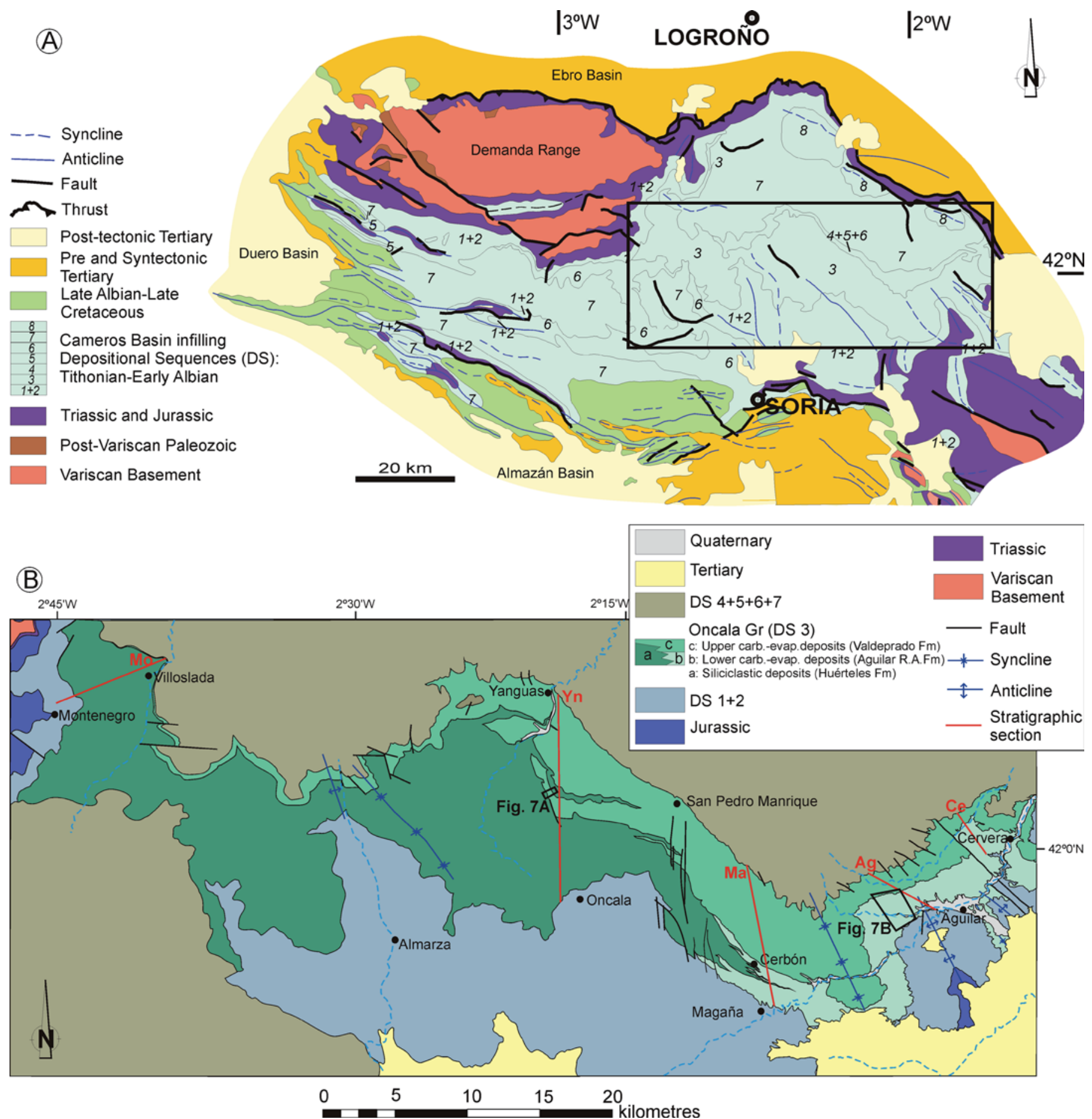

Fig. 3.- A- Geological map of the Cameros Basin (modified from Mas et al., 2002). The rectangle marks the mapped area in Part B. B- Geological map of the Oncala Group. Lateral and vertical facies changes are gradual, so the limits between the units separate predominantly siliciclastic deposits from dominantly carbonate-evaporitic deposits. Red lines mark the location of the stratigraphic sections from the base to the top of the Oncala Group analysed in the present study, and shown in figure 4. Mo = Montenegro section, Yn = Yanguas section, Ma = Magaña section, Ag = Aguilar section, $\mathrm{Ce}=$ Cervera section, Aguilar R.A. Fm = Aguilar del Río Alhama Formation .

Fig. 3.- A- Mapa geológico de la Cuenca de Cameros (modificada de Mas et al., 2002). El rectángulo señala el área cartografiada en la Parte B. B- Mapa geológico del Grupo Oncala. Los cambios laterales y verticales de facies son graduales, de forma que los límites entre unidades separan depósitos predominantemente siliciclásticos de depósitos predominantemente carbonático-evaporíticos. Las líneas rojas indican la localización de las columnas estratigráficas del Grupo Oncala desde la base hasta el techo analizadas en este estudio y mostradas en la figura 4 . Mo $=$ columna de Montenegro, $\mathrm{Yn}=$ columna de Yanguas, $\mathrm{Ma}=$ columna de Magaña, Ag = columna de Aguilar, $\mathrm{Ce}=$ columna de Cervera, Aguilar R.A. Fm = Aguilar del Río Alhama Formation. 
ies state that the siliciclastic succession of central areas of the Oncala Group deposited in broad tidal flats (Quijada et al., 2010b; 2014), and the upper carbonate-evaporitic deposits were developed in shallow, carbonate-sulphate water bodies and their peripheral mudflats (Quijada et al., 2013). Moreover, the latter interpretation is consistent with studies on the ostracod assemblages of the Oncala Group, which indicate mixed fresh and brackish water conditions with marine incursions (Schudack and Schudack, 2009).

\section{Methods}

Geological mapping of the Oncala Group, including its limits, lithostratigraphic units, and tectonic structures, was performed using field observations, aerial photographs, and satellite images. All the obtained cartographic information was georeferenced using the ArcGIS program, the map shown in Figure 3B having been created with this software.

Four selected stratigraphic sections (Yanguas, Magaña, Aguilar, and Cervera sections) were logged in detail from base to top of the Oncala Group in the central and eastern areas of this unit (Figs. 3B, 4), collecting data on bed thickness, lithology, sediment grain size, sedimentary structures, paleocurrents, and fossil content. The sections were logged in the locations where the successions show the best outcropping conditions. Bed thickness measurements were performed at the decimetre scale, and observations at the centimetre and millimetre scale. In addition, 16 individual outcrops and partial stratigraphic sections of the Oncala Group have been studied. Data of the westernmost area of the Oncala Group are based on Gómez-Fernández (1992), as well as on our own observations.

A total of 566 rock samples were collected for laboratory studies. For each sample, a polished and uncovered thin section was prepared to $30 \mu \mathrm{m}$ thickness for petrographic analysis under transmitted-light microscopy. A half of each thin section was stained with Alizarin Red S and potassium ferricyanide (Dickson, 1966).

In order to analyse the relationships of the Oncala Group with other Berriasian deposits in Iberia an exhaustive bibliographic study has been carried out, including the compilation of stratigraphic and sedimentological information from scientific articles, 1:50000 geological maps edited by the Spanish Geological Survey (I.G.M.E.) and the Catalonian Geological Survey (I.G.C.), and synthetic stratigraphic sections of oil exploration wells, included in Lanaja and Navarro (1987). The information obtained from this bibliographic study has been summarized in a map created with the ArcGIS program by adding the points which show the location of the outcrops and wells that contain Berriasian rocks (Fig. 5). Chronostratigraphic information of the used 1:50000 maps has been revised on the basis of the data published in more recent publications. The added points have been coloured according to their sedimentary environment, as stated in the existing literature.

\section{Stratigraphic framework}

The Oncala Group was originally defined by Tischer (1966) mainly for the lower carbonate units deposited in the Cameros Basin (Fig.6). This definition was also used by Clemente (2010), who also included the carbonate deposits of the Tera Group (see Fig. 2) located in southern and southeastern areas of the Demanda Range, and the Leza Formation within this group. Gómez-Fernández (1992), Mas et al. (1993), and Gómez-Fernández and Meléndez (1994b) redefined the Oncala Group to include only the sediments of the third depositional sequence of eastern Cameros Basin. The latter definition is widely used nowadays, and it is used in the present study. The Oncala Group as defined by Gómez-Fernández (1992), Mas et al. (1993), and Gómez-Fernández and Meléndez (1994b), corresponds to Cycles IIC and IID proposed by Salomon (1982a; 1982b), and Cyclothem II by Guiraud and Seguret (1985) (Fig. 6). Several authors include the Leza Formation (Fig. 2), which crops out at the northern margin of the Cameros Basin, within the Oncala Group (Hernández-Samaniego et al., 1990; Doublet, 2004; Clemente, 2010), but other authors (Tischer, 1966; Guiraud, 1983; Alonso and Mas, 1990; Mas et al., 1993; MartínClosas and Alonso, 1998; Suarez-Gonzalez et al., 2010) interpret the Leza Formation as part of the Enciso Group (see Fig. 2). Suarez-Gonzalez et al. (this volume) discuss this controversy in depth, and show that the Leza Formation is not part of the Oncala Group, but is included in the Enciso Group.

The Oncala Group contains both siliciclastic and carbonate-evaporitic deposits, which are laterally related, and is characterized by very gradual lateral and vertical changes (Figs. 3B, 4, 6, 7). Siliciclastic deposits are mostly present in western areas of the basin, and they show gradual lateral changes from coarser-grained facies in westernmost areas of the basin to finer-grained sediments eastwards. Carbonate-evaporitic deposits occur in eastern areas of the basin, and they are progressively more extensive towards the upper part of the unit, until they occupy most of the basin (Figs. 3B, 4, 6).

Attending to the lithostratigraphic characteristics, several subdivisions of the Oncala Group have been proposed by different authors (Fig. 6). Salomon (1982a; 


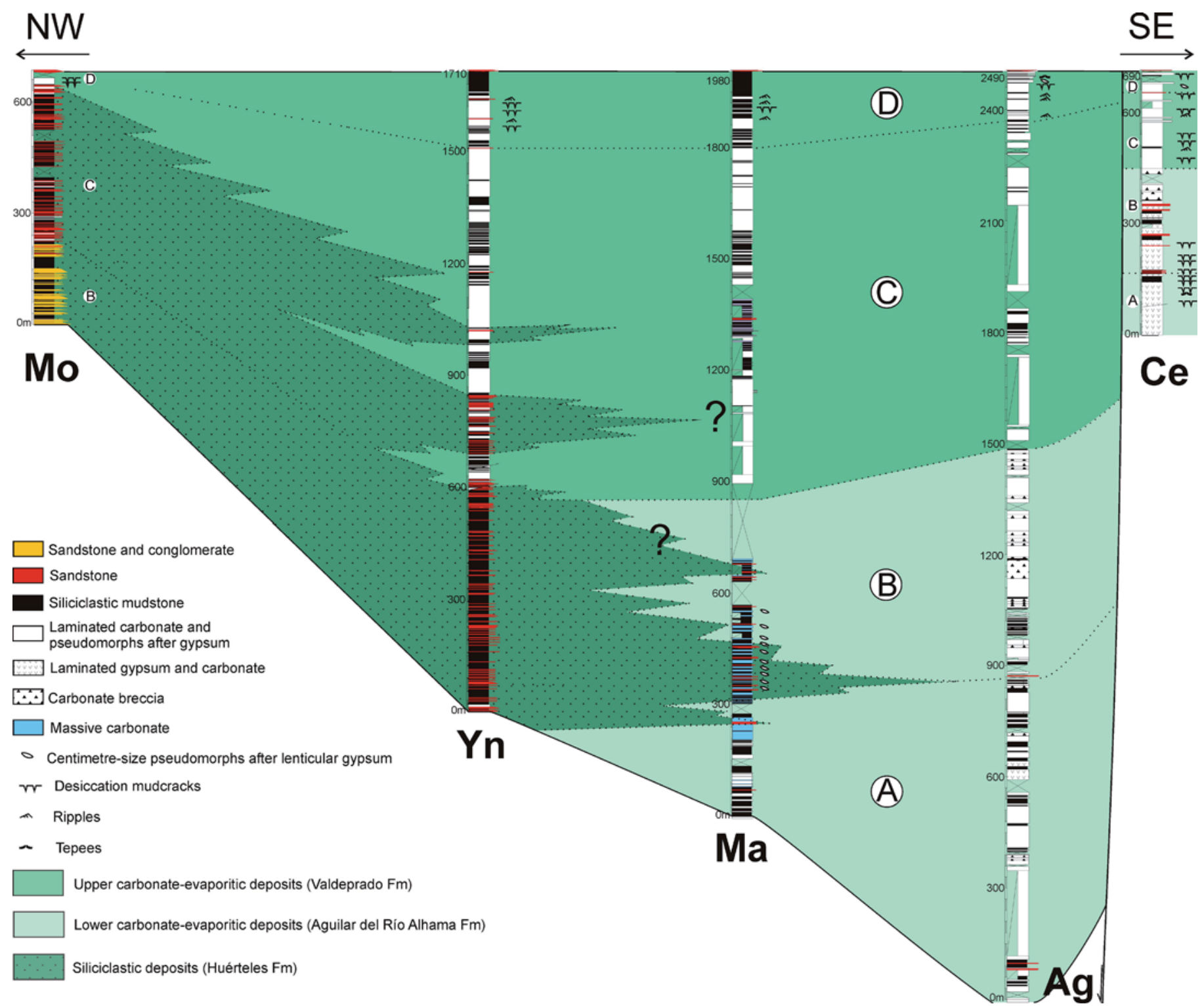

Fig. 4.- Synthetic stratigraphic sections from the base to the top of the Oncala Group and its correlation. Note the gradual, lateral and vertical facies changes of siliciclastic deposits with both lower and upper carbonate-evaporitic deposits. Location of the sections is marked in figure 3B. Mo- Stratigraphic section of Montenegro (based on data by Gómez-Fernández, 1992; Mas et al., 2011; and personal observations). Yn = Yanguas section, $\mathrm{Ma}=$ Magaña section, $\mathrm{Ag}=$ Aguilar section, $\mathrm{Ce}=$ Cervera section. Letters $\mathrm{A}$ to $\mathrm{D}$ indicate the four main stratigraphic intervals recognized in the Oncala Group.

Fig. 4.- Secciones estratigráficas sintéticas del Grupo Oncala desde la base hasta el techo y su correlación. Obsérvense los cambios laterales y verticales de facies graduales entre los depósitos siliciclásticos y los depósitos carbonático-evaporíticos inferiores y superiores. La localización de las columnas se muestra en la figura 3B. Mo- Columna estratigráfica de Montenegro (basada en datos de Gómez-Fernández, 1992; Mas et al., 2011; y observaciones personales). $\mathrm{Yn}=$ Columna de Yanguas, $\mathrm{Ma}=$ Columna de Magaña, $\mathrm{Ag}=$ Columna de Aguilar, $\mathrm{Ce}=\mathrm{Columna}$ de Cervera Las letras A a D indican los cuatro intervalos estratigráficos principales reconocidos en el Grupo Oncala.

1982b) divided these deposits in two phases, and defined seven different facies. Guiraud and Seguret (1985) divided the Oncala Group into two phases almost identical to those of Salomon (1982a; 1982b), but these authors defined only three formations. The lower phase was subdivided in a predominantly siliciclastic Huérteles Formation and a predominantly carbonate Aguilar Formation. The Valdeprado Formation was defined for the gypsiferous laminated carbonates of the upper phase.
Gómez-Fernández (1992) and Gómez-Fernández and Meléndez (1994b) subdivided the Oncala Group into two alloformations separated by an unconformity: the Huérteles Alloformation and Valdeprado Alloformation. Both alloformations contain laterally related siliciclastic and carbonate-evaporitic deposits. The lower Huérteles Alloformation is not present in the westernmost area of the basin, whereas the upper Valdeprado Alloformation is present in the entire eastern Cameros Basin. 


\section{Sediments of the Oncala Group}

Sediments of the Oncala Group are studied in detail in this work. In order to analyse the lateral and vertical changes that occur within this unit, different areas of the basin are described separately.

\subsection{Western area of the Oncala Group}

Deposits of the western area of the Oncala Group, which are mainly made up of siliciclastic facies, crop out in the area of the town of Montenegro de Cameros (Fig. 4, Mo stratigraphic section), comprising around $650 \mathrm{~m}$ of sediments (Gómez-Fernández, 1992; Gómez-Fernández and Meléndez, 1994b). In this study, sediments of the western area of the Oncala Group are divided in three main intervals based on their facies associations.

The lowermost interval (interval B of Fig. 4) consists of sandstone bodies, and less abundant conglomerate bodies, interbedded with red lutites (Gómez-Fernández, 1992; Meléndez and Gómez-Fernández, 2000). According to these authors, sandstone bodies are up to $6 \mathrm{~m}$ thick, and they display erosive bases and trough cross-stratification. The conglomerate bodies are approximately $4 \mathrm{~m}$ thick, and display erosive bases. They consist of up to $50 \mathrm{~cm}$-thick tabular massive bodies. The red lutites are massive, and commonly show pedogenic features, such as nodulization and rhizoliths. Sandstone meander loop bodies are also present in the upper part of this interval.

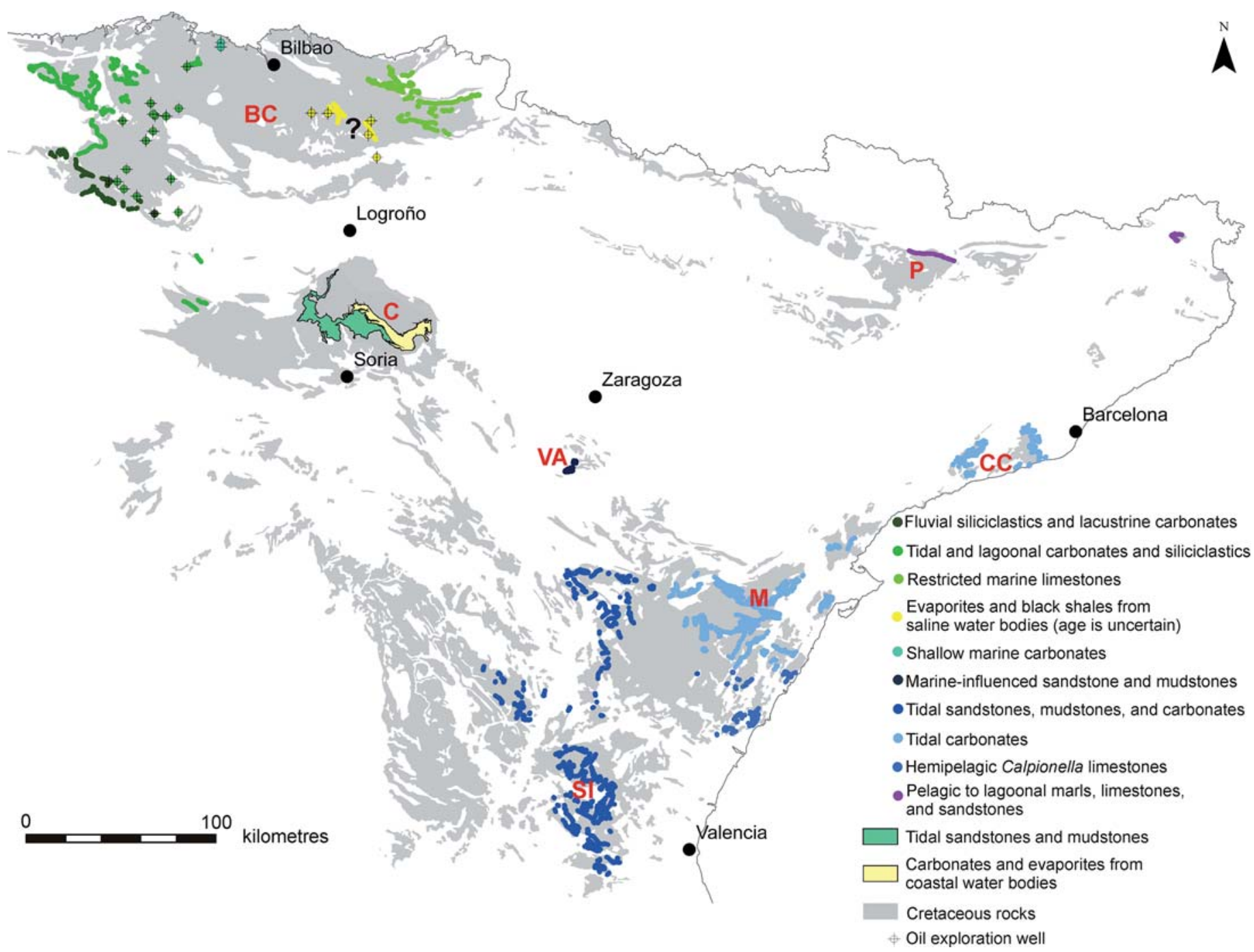

Fig. 5.- Synthetic map showing the location and main facies of Berriasian deposits in the Iberian Peninsula. Note the strong similarities of the facies of the Oncala Group with the facies of Berriasian deposits of the Basque-Cantabrian Basin. $\mathrm{BC}=$ Basque-Cantabrian Basin, $\mathrm{C}=\mathrm{Cameros}$ Basin, VA = Villanueva de Huerva and Aguilón sectors, SI = South Iberian Basin, $\mathrm{M}=$ Maestrat Basin, $\mathrm{CC}=$ Catalonian Coastal Ranges, $\mathrm{P}=$ Pyrenean Basin.

Fig. 5.- Mapa sintético mostrando la localización y facies predominantes de los depósitos berriasienses de la Península Ibérica. Obsérvense las importantes similitudes entre las facies del Grupo Oncala y las facies de los depósitos berriasienses de la Cuenca Vasco-Cantábrica. $\mathrm{BC}=$ Cuenca Vasco-Cantábrica, $\mathrm{C}=$ Cuenca de Cameros, $\mathrm{VA}=$ Sectores de Villanueva de Huerva y Aguilón, $\mathrm{SI}=$ Cuenca Suribérica, $\mathrm{M}=\mathrm{Cuenca}$ del Maestrat, $\mathrm{CC}=$ Cordillera Costero Catalana, $\mathrm{P}=$ Pirineos. 
The next interval (interval C of Mo, Fig. 4) contains mainly sandstone meander loop bodies, which are made up of lateral accretion units, and lutites, interbedded with black peloidal carbonates and black shales (Gómez-Fernández, 1992; Mas et al., 2011). Carbonates are commonly laminated, and contain ostracods, charophytes, bivalves, gastropods, and vertebrate and plant remains. The proportion of carbonates relative to sandstones increases upwards the succession.

The third interval (interval D of Mo, Fig. 4) consists exclusively of black carbonates with abundant desiccation mudcracks and black shales (Mas et al., 2011).

\subsection{Central area of the Oncala Group}

The deposits of the central area of the Oncala Group are studied in detail in the stratigraphic sections of Yanguas and Magaña (Fig. 4, Yn and Ma stratigraphic sections). The central area of the Oncala Group comprises up to $2000 \mathrm{~m}$ of sediments, and contains both siliciclastic and carbonate-evaporitic deposits. Four main intervals are recognized in the central area of the Oncala Group.

Interval A of the stratigraphic section of Magaña (Fig. 4) is made up of alternating laminae of carbonate mudstone and calcite and quartz pseudomorphs after gypsum, interbedded with shales and some sandstones, which are more common upwards. Interval A of the stratigraphic section of Yanguas consists of laterally extensive heterolithic layers and meander loop bodies, interbedded with some carbonate layers.

Interval B of sections Yn and Ma (Fig. 4) contains mostly siliciclastic deposits (analysed in detail by Quijada et al. 2010; 2014), which consist of laterally extensive heterolithic layers and less abundant, meander loop bodies (Fig. 8A, B). Laterally extensive layers (tens to hundreds of metres wide) are made up of interlaminated siliciclastic mudstone and sandstone, displaying lenticular, wavy, and flaser stratification, and ubiquitous desiccation mudcracks and vertebrate footprints. Meander loop bodies are tabular, with widths of up to $70 \mathrm{~m}$ and thicknesses of 1-3 $\mathrm{m}$. They are formed by one or more adjoined point bar bodies limited by reactivation surfaces (Fig. 8A). Point bar bodies fine upwards, and display inclined heterolithic stratification (IHS) and flaser, wavy and lenticular bedding (Fig. 8C). Desiccation mudcracks and vertebrate footprints are common in the upper part of the point bars. Fossil content is scarce in both laterally extensive layers and meander loop bodies, and it includes fragments of bones, ostracods, and rare charophytes. Predominant paleocurrents indicate transport directions to East and Southeast, but occasionally they may display bidirectional pattern. These siliciclastic deposits pass eastwards to, and are interbedded with, generally massive, carbonate mudstones with centimetre-size, calcite and quartz pseudomorphs after lenticular gypsum (Fig. 4, interval B of Ma, Figs. 8D, E).

Interval $\mathrm{C}$ of sections $\mathrm{Yn}$ and $\mathrm{Ma}$ (Fig. 4) consists of interbedded parallel-laminated, carbonate-evaporitic deposits and siliciclastic deposits (Figs. 7A, 9A, 9B), which include meander loop bodies, laterally extensive heterolithic layers, and black shales. The parallel-laminated carbonate-evaporitic deposits consist of an alternation of laminae of carbonate mudstone and (sub-) millimetre-size calcite and quartz pseudomorphs after gypsum (Quijada et al., 2013). Pseudomorphs after gypsum are interpreted as originally lenticular gypsum crystals and detrital gypsum. Fossil content is limited to ostracods, rare charophytes, and stromatolites, and some carbonate layers contain peloids. Siliciclastic layers are more common to the West, and they are progressively less abundant eastwards and upwards, eventually disappearing in the upper part of this interval (Fig. 4).

Interval D of sections Yn and Ma (Fig. 4) consists also of parallel-laminated, carbonate-evaporitic deposits, but they display lower proportion of evaporites, abundant ripples, desiccation mudcracks (Fig. 9C), centimetre-size pseudomorphs after gypsum, and a higher fossil content, which includes ostracods and gastropods. Some laterally extensive sandstone layers interbedded with laminated carbonate-evaporitic deposits are present to the West in the Yanguas stratigraphic section.

\subsection{Eastern area of the Oncala Group}

The deposits of the eastern area of the basin are studied in the stratigraphic section of Aguilar (Ag, Fig. 4), which contains the thickest sedimentary infill of the Oncala Group, comprising up to $2500 \mathrm{~m}$ of sediments of mainly carbonate-evaporitic deposits. Four main intervals are recognized in this area (A to D of Ag section, Fig. 4).

Interval A (Fig. 4) is made up of an alternation of laminae of carbonate mudstone and gypsum, which commonly has been replaced by calcite and quartz (Fig. 9D, E). Evaporitic layers were originally made up of displacive and detrital gypsum, and rare selenite crystals. Desiccation mudcracks filled with pseudomorphs after lenticular gypsum are present at the top of some carbonate laminae. Fossil content includes ostracods, and rare charophytes. The amount of evaporitic laminae and its thicknesses increase towards the eastern areas of the basin. These carbonate-evaporitic laminae are interbedded with shales, commonly displaying desiccation mudcracks, and carbonate breccias (Fig. 9D), which consist of millimetre to 10 centimetre-size, rectangular fragments of carbon- 


\section{Tischer (1966)}
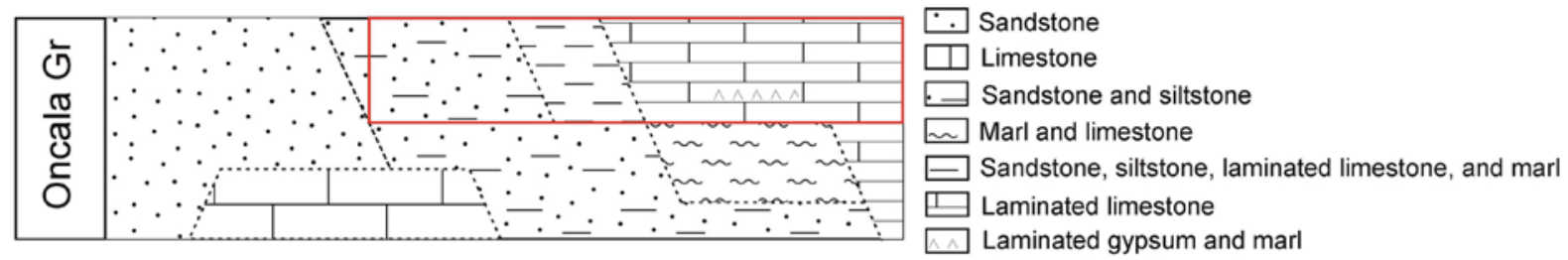

Salomon (1982a; 1982b)
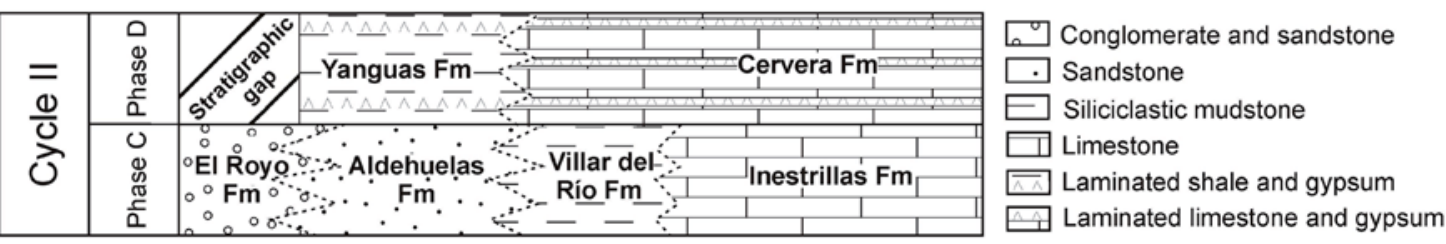

\section{Guiraud and Seguret (1985)}

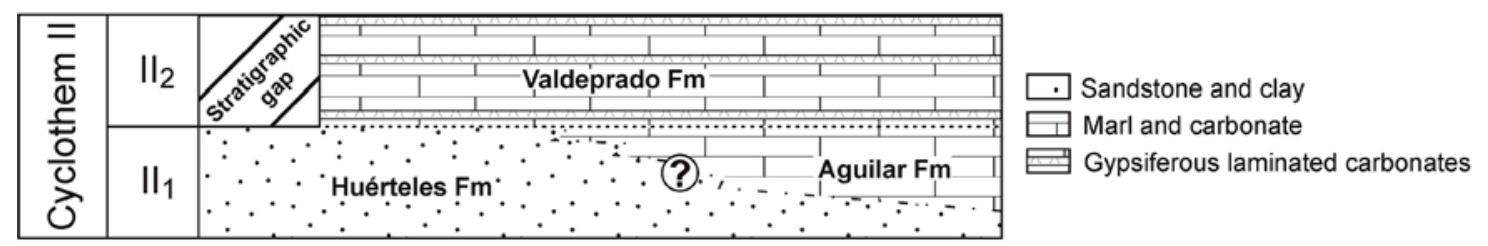

\section{Gómez-Fernández (1992), Gómez-Fernández and Meléndez (1994)}
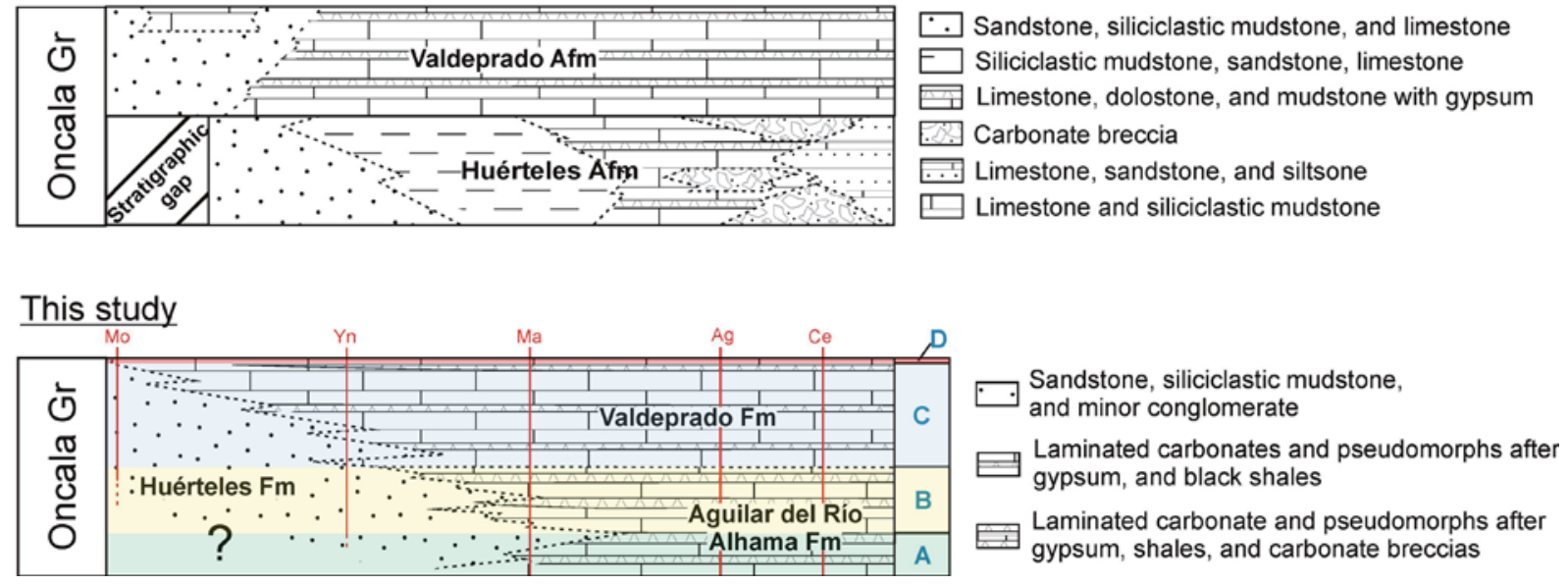

Fig. 6.- Subdivisions of the Oncala Group proposed by different authors. The red rectangle within the chart that shows the subdivisions by Tischer (1966) marks the deposits that are considered part of the Oncala Group nowadays, and the rest of the deposits are currently included within the Tera Group (see Fig. 2). The letters A to D of the chart that shows the subdivisions of this study indicate the four main stratigraphic intervals recognized in the Oncala Group.

Fig. 6.- Subdivisiones propuestas para el Grupo Oncala por diversos autores. El rectángulo rojo del cuadro que muestra las subdivisiones de Tischer (1966) señala los depósitos que actualmente se consideran parte del Grupo Oncala y el resto de los depósitos se incluyen en la actualidad en el Grupo Tera (ver Fig. 2). Las letras A a D del cuadro que muestra las divisiones del presente estudio indican los cuatro intervalos principales reconocidos en el Grupo Oncala.

ate mudstone with pseudomorphs after gypsum, floating in a pseudosparitic calcite matrix. The breccias are interpreted as the result of tectonic deformation affecting alternating carbonate and sulphate laminae (Quijada et al., 2012; 2013).
Interval B (Fig. 4) contains the same facies as interval A, but the amount of carbonate breccias is much larger, and laterally extensive sandstone layers, although rare, are also present. The amount of evaporitic laminae and breccias and its thicknesses increase also towards the 

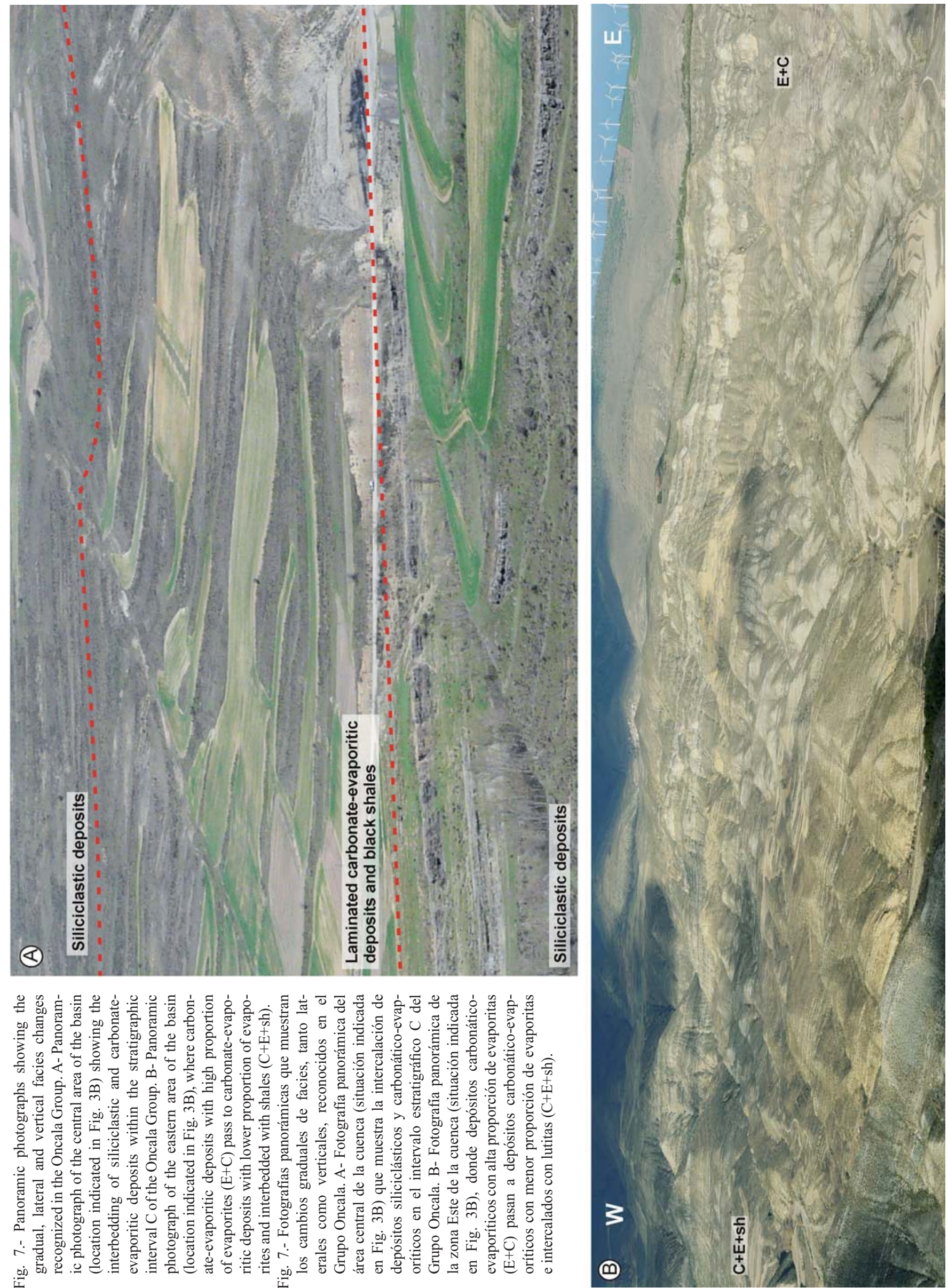

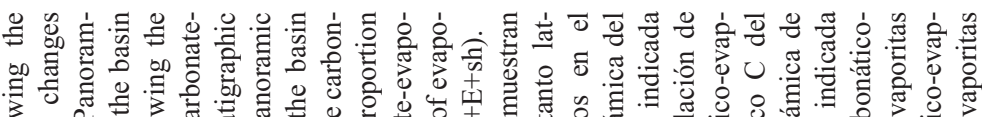

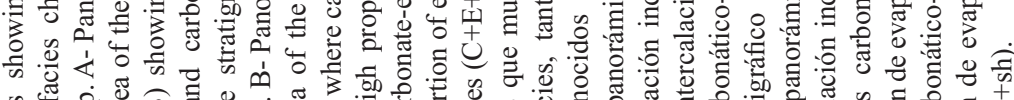

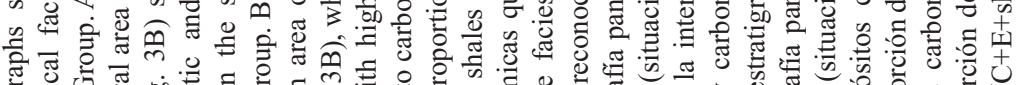

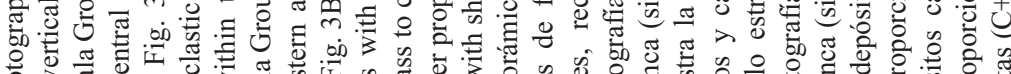

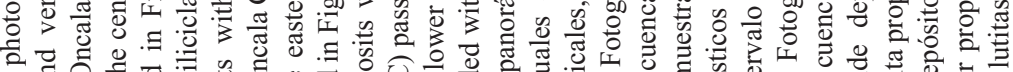

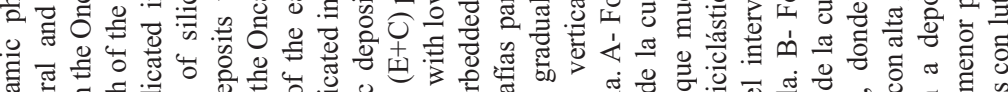

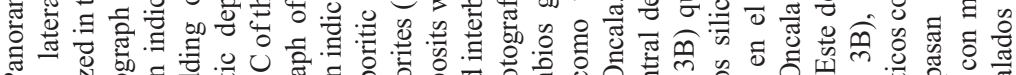

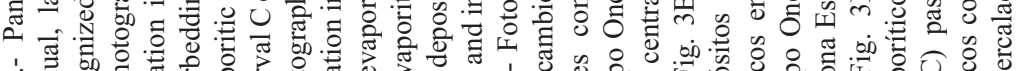

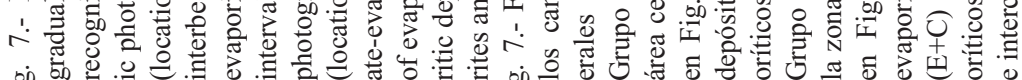
架 
eastern areas of the basin in this interval (Fig. 7B).

Interval C (Fig. 4) consists of parallel-laminated, carbonate-evaporitic deposits interbedded with shales, identical to those in the central area of the basin (interval $\mathrm{C}$ of Yn and Ma in Fig. 4). These carbonate-evaporitic deposits are distinguishable from those of the intervals $\mathrm{A}$ and $\mathrm{B}$ in the Aguilar section due to more conspicuous, continuous, parallel lamination, comparatively less amount of pseudomorphs after gypsum, and scarcity of carbonate breccias (Fig. 4). Sporadic desiccation mudcracks are present in interval C. Fossil content includes ostracods, stromatolites, and according to Gómez-Fernández (1992) and Meléndez and Gómez-Fernández (2000), very scarce foraminifera.

Interval D (Fig. 4) is very similar to that of the central area because it consists of parallel-laminated, carbonateevaporitic deposits with lower proportion of evaporites, ripples, centimetre-size pseudomorphs after gypsum, desiccation mudcracks, rare tepees, ostracods, gastropods, and bivalves.

\subsection{Easternmost area of the Oncala Group}

The easternmost area of the Oncala Group is studied in the stratigraphic section of Cervera, which comprises 720 $\mathrm{m}$ of sediments (Ce, Fig. 4), and despite the differences in thickness, shows many parallelisms with the adjacent area of Aguilar (Ag, Fig. 4). Four main stratigraphic intervals (A to D of Ce stratigraphic section, Fig. 4) are recognized in this area.

Interval A (Fig. 4) is made up of alternating laminae of carbonate mudstone and gypsum (Fig. 9F). Desiccation mudcracks are common at the top of the carbonate laminae, in contrast with deposits of the interval $\mathrm{A}$ in the adjacent Aguilar stratigraphic section (Fig. 4). Evaporitic laminae, now made up of secondary gypsum, were probably originally made up of lenticular gypsum crystals, detrital gypsum, and less abundant selenite gypsum crystals (Quijada et al., 2010a). Sulphur isotopic composition of the secondary gypsum has values ranging from 17.8 to $20.3 \%_{\mathrm{V}-\mathrm{CDT}}$, and the mean value is $18.2 \%_{\mathrm{V}-\mathrm{CDT}}$ (AlonsoAzcárate et al., 2006).

Interval B (Fig. 4) is characterized by the presence of sandstone-mudstone layers and carbonate breccias in addition to alternating laminae of carbonate mudstone and secondary gypsum. Sandstone-mudstone layers are up to $6 \mathrm{~m}$ thick and laterally very extensive (hundreds of metres wide), and show flat bases and tops. They display lenticular, wavy and flaser stratification. Desiccation mudcracks are abundant at the top of the siliciclastic and carbonate mudstones. Paleocurrents indicate transport directions to the South.
Interval C (Fig. 4) is made up of parallel-laminated, carbonate-evaporitic deposits, with abundant stromatolites and rare peloidal carbonate layers, made up of alternating laminae of peloid packstone and grainstone. The uppermost interval D (Fig. 4) is also made up of parallel-laminated, carbonate-evaporitic deposits with lower proportion of evaporites, centimetre-size pseudomorphs after gypsum, desiccation mudcracks, and larger fossil content.

\section{Discussion}

\subsection{Sedimentological interpretation}

Attending to lithological characteristics, the deposits of the Oncala Group can be classified in two main groups: siliciclastic deposits, which occur mostly in western areas of the basin, and carbonate-evaporitic deposits, which are more abundant eastwards. Firstly, the sedimentological characteristics of the siliciclastic and carbonate-evaporitic deposits are discussed separately; then, in order to make a paleogeographical interpretation of the Oncala Group, the lateral relationships of both types of deposits are analysed.

\section{Siliciclastic deposits}

Siliciclastic deposits of the Oncala Group occur in western to central areas of the basin, and show very gradual lateral and vertical facies changes. Westernmost areas of the basin (Mo section, Figs. 3B, 4) contain conglomerate and trough cross-stratified sandstone bodies in the lower part of the succession (interval B of Mo, Fig. 4), which were formed in braided fluvial systems, according to Gómez-Fernández (1992) and Meléndez and Gómez-Fernández (2000). These conglomerate and sandstone bodies progressively change upwards to sandstone meander loop bodies (interval C of Mo, Fig. 4), which were probably deposited in meandering fluvial systems (Gómez-Fernández, 1992; Meléndez and Gómez-Fernández, 2000).

Towards central areas of the basin, the fluvial deposits pass to laterally extensive heterolithic layers and meander loop bodies (intervals A to C of Yn and Ma, Fig. 4). Contrarily to previous interpretations of the deposits of central areas of the basin as continental sandy-muddy flat deposits (Gómez-Fernández, 1992; Meléndez and Gómez-Fernández, 2000), recent studies demonstrate that they were formed in broad, low-gradient, inter- to supratidal flats, traversed by shallow, meandering channels (Quijada et al., 2014). The criteria that led to this interpretation are: the presence of meander loop bodies displaying low angle, lateral accretion units and IHS (Fig. 
$8 \mathrm{~A})$; alternation of sandstone and mudstone laminae that form lenticular, wavy and flaser bedding (Fig. 8C); rhythmic variations in the type of bedding and the thicknesses of the sandstone-mudstone couplets; abundant evidence of subaerial exposure at the top of numerous, consecutive laminae; predominance of non-channelled facies over meander loop bodies (Fig. 8B); and the fine grain size of the sediments and large amount of mudstone.

\section{Carbonate-evaporitic deposits}

The carbonate-evaporitic deposits can be divided in a lower and an upper group, attending to facies differences.

The lower carbonate-evaporitic deposits (stratigraphic intervals $\mathrm{A}$ and $\mathrm{B}$ of $\mathrm{Ma}, \mathrm{Ag}$, and Ce, Figs. 4, 9D, 9E), which contain large amounts of evaporites, carbonate breccias, and shales with desiccation mudcracks, are interpreted as formed in shallow, carbonate-sulphate water bodies and saline mudflats (Gómez-Fernández, 1992; Gómez-Fernández and Meléndez, 1994a; Quijada, 2009). The sulphur isotope composition of the gypsum of the easternmost area of the basin (17.8 to $\left.20.3 \% \mathrm{o}_{\mathrm{V}-\mathrm{CDT}}\right)$ led Alonso-Azcárate et al. (2006) to interpret that the main source of sulphate was probably the recycling of Triassic evaporites, which have $\delta^{34} \mathrm{~S}$ compositions around $14.5 \%$, and that the sulphur isotope composition was modified by bacterial sulphate reduction in the water bodies. Nonetheless, they also suggested that Berriasian seawater could have been an additional source of sulphate in the Cameros Basin. However, recent seawater sulphur isotope curves for the Cretaceous indicate that lowermost Cretaceous seawater had values of around 20\% (Paytan et al., 2004; Paytan and Gray, 2012). This value matches the composition of the gypsum of the Oncala Group, suggesting that it is more plausible that the source of sulphate was the Berriasian seawater. This possibility is reinforced by the fact that these carbonate-evaporitic deposits are laterally related with tidal flat deposits, and by the large amount of sulphate that precipitated in the Oncala Group. Although seawater input was recurrent, the water bodies were somehow confined, so water loss exceeded inflow, and consequently, salinity increased to gypsum supersaturation point (cf. Warren, 2006; Ortí, 2010).

The upper carbonate-evaporitic deposits (intervals $\mathrm{C}$ and D of Yn, Ma, Ag, and Ce, Fig. 4), which consist of parallel-laminated alternating carbonate mudstone and pseudomorphs after gypsum, contain slightly less proportion of pseudomorphs after sulphates relative to carbonates than the lower carbonate-evaporitic deposits, and show more conspicuous lamination (Figs. 9A, B). Contrarily to previous interpretations that ascribed a deep lacustrine origin to the upper carbonate-evaporitic deposits (Gómez-Fernández, 1992; Meléndez and Gómez-Fern- ández, 2000), recent studies indicate that they accumulated in shallow, perennial, carbonate-sulphate water bodies (Quijada et al., 2013). This interpretation is based on the presence of sporadic desiccation mudcracks, which are very abundant in some stratigraphic intervals (Fig. 9C); presence of rippled carbonates; interbedding of parallellaminated carbonate-sulphate deposits with carbonate displaying centimetre-size pseudomorphs after gypsum, tepees, and desiccation cracks; absence of marked slope gradients in the basin; presence of the same laminated carbonate facies along tens of kilometres; and direct interbedding and lateral change with siliciclastic sandymuddy flat deposits (fig. 7A). Salinities in the upper carbonate-sulphate water bodies were likely slightly lower than during deposition of the lower carbonate-evaporitic deposits, because sulphate deposits are less abundant.

Both the lower and upper carbonate-evaporitic deposits show less abundant pseudomorphs after gypsum in the areas adjacent to the siliciclastic deposits (Fig. 7B), which probably indicates lower salinities. This could be related with more freshwater input in these areas, probably coming from the siliciclastic fluvial system located to the west (Mo section, Fig. 4), and thus, relative smaller influence of marine waters.

\section{Paleogeographic reconstruction of the Oncala Group}

The presence of the same facies associations along tens of kilometres in the Oncala Group, the very gradual, lateral and vertical facies changes that characterize this unit (Fig. 4) and the presence of facies deposited only in shallow water environments, suggest that the sediments of the Oncala Group were developed in very broad, low-gradient, shallow areas. These broad shallow areas were occupied by rivers and floodplains in the westernmost area of the basin, tidal flats in western and central areas, and carbonate-sulphate water bodies in central and eastern areas (Fig. 10A). These depositional systems were laterally related, as shows the gradual, lateral and vertical facies changes between the siliciclastic and the carbonate-evaporitic deposits of the Oncala Group (Figs. 4, 10A). Both siliciclastic tidal flats and carbonate-evaporitic water bodies had marine connection, as indicate respectively the influence of tidal currents, and the large sulphate input and sulphur isotope compositions. Moreover, the ostracod assemblages of the Oncala Group indicate mixed fresh and brackish water conditions with marine incursions (Schudack and Schudack, 2009). The evidence of marine influence in these two systems suggests that a broad, coastal, protected, shallow embayment was developed in the eastern sector of the Cameros Basin during Berriasian times. According to the facies distribution, the basin received freshwater and siliciclastic input from westernmost areas. 

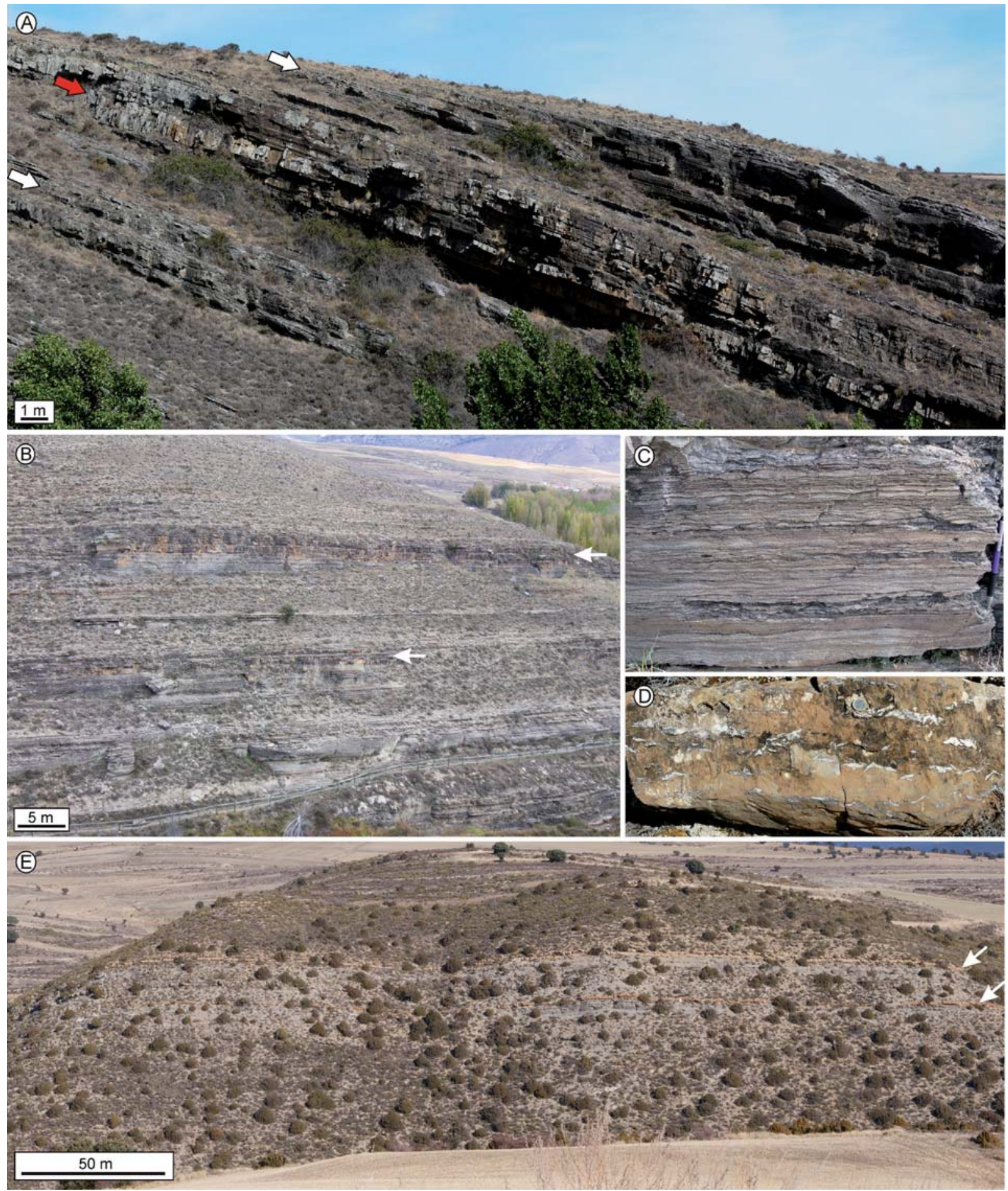

Fig. 8.- A- Field photograph of a meander loop body (red arrow) interbedded with laterally extensive heterolithic layers (white arrows). B- Field photograph showing the laterally extensive heterolithic layers and less abundant, meander loop bodies (marked with arrows). C- Field photograph showing flaser, wavy and lenticular bedding within lateral accretion units of a meander loop body. Pencil for scale in right area of the photograph. D- Field photograph of a massive carbonate mudstone layer with centimetre-size, calcite and quartz pseudomorphs after lenticular gypsum of the Aguilar del Río Alhama Formation. Diameter of the coin in upper central area of the photograph is $23 \mathrm{~mm}$. E- Field photograph showing interbedded siliciclastic layers of the Huérteles Formation (grey colour) and massive carbonate layers of the Aguilar del Río Alhama Formation (orange colour, marked with arrows).

Fig. 8.- A- Fotografía de campo de un lóbulo de meandro (flecha roja) intercalado con capas heterolíticas lateralmente extensas (flechas blancas). B- Fotografía de campo que muestra capas heterolíticas lateralmente extensas y lóbulos de meandros menos abundantes (señalados con flechas). C-Fotografía de laminación flaser, ondulada y lenticular en unidades de acreción lateral de un lóbulo de meandro. Portaminas de escala en la parte derecha de la fotografía. D- Fotografía de campo de una capa de carbonato mudstone masivo con pseudomorfos centimétricos de yeso reemplazados por calcita y cuarzo de la Formación Aguilar del Río Alhama. El diámetro de la moneda situada en la parte central superior de la fotografía es de 23 $\mathrm{mm}$. E- Fotografía de campo que muestra depósitos siliciclásticos de la Formación Huérteles (color gris) intercalados con capas carbonáticas masivas de la Formación Aguilar del Río Alhama (color naranja, señaladas con flechas). 

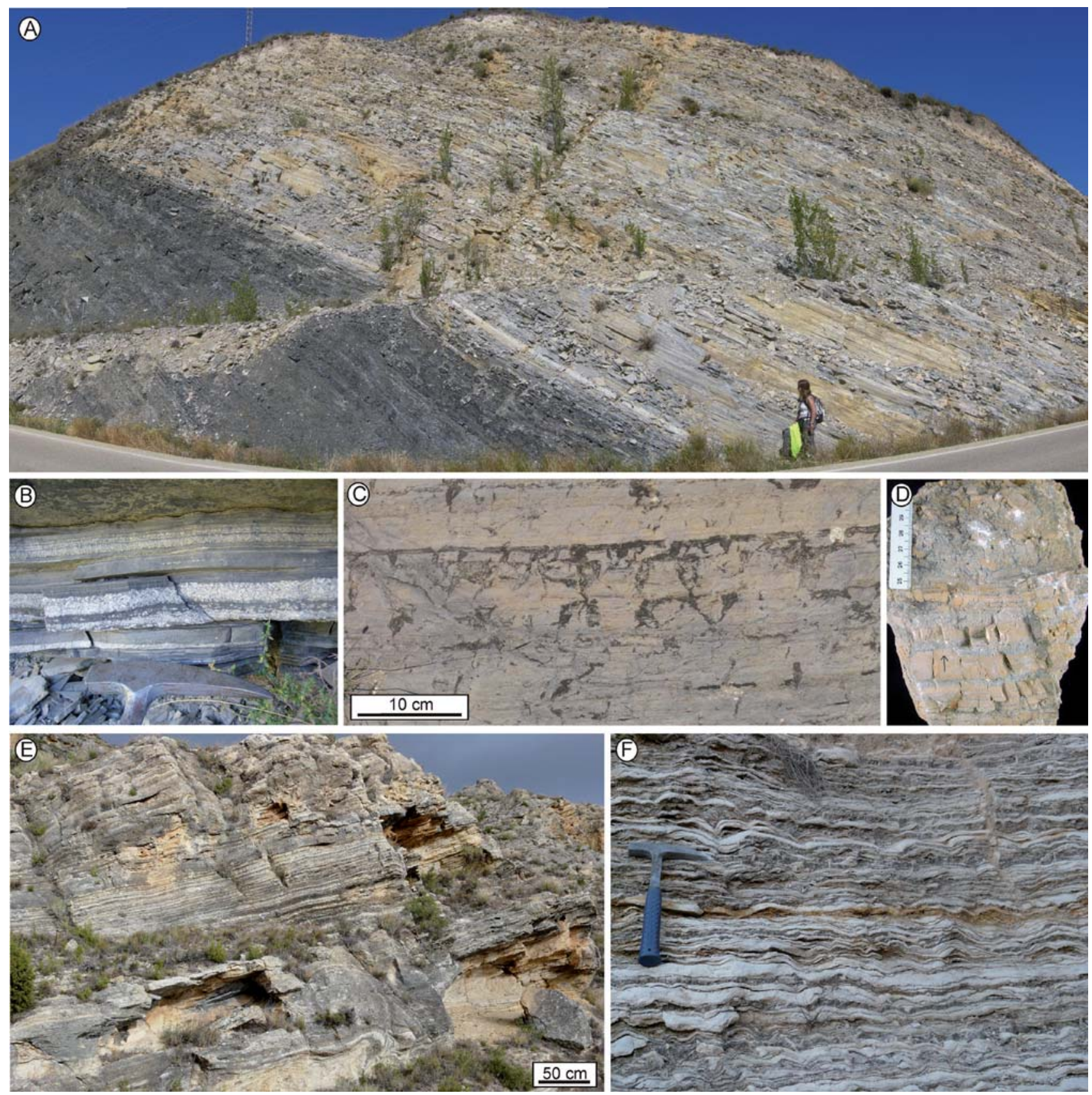

Fig. 9.- A- Field photograph of the Valdeprado Formation showing the continuous parallel lamination that characterizes this unit. Black deposits in the left area of the photograph are black shales, and light-colour deposits in the right area are alternating laminae of carbonate mudstone and pseudomorphs after gypsum. B- Field photograph of the alternation of laminae of carbonate mudstone and calcite and quartz pseudomorphs after gypsum of the Valdeprado Formation. Hammer for scale in the lower part of the photograph. C- Field photograph of the carbonate-evaporitic deposits of the stratigraphic interval D displaying abundant desiccation mudcracks (Valdeprado Formation). D- Photograph of a sample of carbonate-evaporitic deposits of the Aguilar del Río Alhama Formation. The lower part of the sample consists of an alternation of laminae of carbonate mudstone and calcite pseudomorphs after gypsum, and the upper part consists of a carbonate breccia. Scale bar is in centimetres. E- Field photograph of the carbonate-evaporitic deposits of the Aguilar del Río Alhama Formation. Note the laminated aspect they present. F- Field photograph of the alternation of laminae of carbonate mudstone and secondary gypsum of the Aguilar del Río Alhama Formation in easternmost areas of the basin (Ce stratigraphic section).

Fig. 9.- A- Fotografía de campo de la Formación Valdeprado que muestra la laminación paralela continua que caracteriza a esta unidad. Los depósitos negros de la parte izquierda de la fotografía son black shales y los depósitos de color claro de la parte derecha son una alternancia de láminas de carbonato mudstone y pseudomorfos de yeso. B- Fotografía de campo de la alternancia de láminas de carbonato mudstone y pseudomorfos de yeso reemplazados por calcita y cuarzo de la Formación Valdeprado. Martillo de escala en la parte inferior de la fotografía. C- Fotografía de campo de los depósitos carbonático-evaporíticos con abundantes grietas de desecación del intervalo estratigráfico D (Formación Valdeprado). D- Fotografía de una muestra de los depósitos carbonático-evaporíticos de la Formación Aguilar del Río Alhama. La parte inferior de la muestra está formada por una alternancia de láminas de carbonato mudstone y pseudomorfos de yeso reemplazados por calcita, y la parte alta consiste en una brecha carbonática. La escala está en centímetros. E- Fotografía de campo de los depósitos carbonático-evaporíticos de la Formación Aguilar del Río Alhama. Nótese el aspecto laminado que presentan. F- Fotografía de campo de la alternancia de láminas de carbonato mudstone y yeso secundario de la Formación Aguilar del Río Alhama en la zona más oriental de la cuenca (columna estratigráfica Ce). 
The siliciclastic source was probably the Demanda Massif (Figs. 3A, 10A), which began to behave as a paleogeographic high since the Late Jurassic (Alonso et al., 1986-1987; Benito and Mas, 2006). Abundant freshwater discharges from rivers into the tidal siliciclastic system may have impeded the presence of marine fossils in the Oncala Group, although additional causes, such as high rates of sedimentation, high suspended-sediment concentrations, or strongly acidic waters, cannot be excluded (Quijada et al., 2014).

Some modern sedimentary settings present similarities with the paleoenvironments of the Oncala Group. An example could be the Bombetoka Bay in Madagascar, a large tidal embayment where freshwater from the Betsiboka River mixes with salty water from the sea (Raharmahefa and Kusky, 2010). The large freshwater discharges and strong river dynamics cause the prevalence of freshwater over the marine influences in the Betsiboka Estuary. The Upper San Francisco Estuary/ Sacramento Delta in California is another example of an inland tidal delta located in a protected bay (Brown and Pasternack, 2004) in which fresh to brackish conditions occur (Wells and Goman, 1995). However, these two modern examples do not contain carbonate-evaporitic deposits adjacent to the siliciclastic tidal system, as occurs in the Oncala Group, probably because of lower evaporation/water input rates in these modern environments. The eastern area of the Indus Delta is an example of a tide-dominated siliciclastic system laterally related with a vast evaporitic mudflat that receives seawater input (Inam et al., 2007; Dalrymple and Choi, 2007). These modern coastal evaporitic mudflats occupy a protected area, as it is interpreted for the carbonate-evaporitic system of the Oncala Group.

Moreover, the broad, shallow, carbonate-sulphate water bodies interpreted for the Oncala Group can be compared with ancient, evaporitic epicontinental seaways that spread out across large continental areas (see Warren, 2006, 2010), such as those developed in the Northern Delaware Basin margin, USA, at Permian times (Elliott and Warren, 1989), and in the Arbuckle Group, Oklahoma (USA), during the Ordovician (John and Eby, 1978). These seaways caused covering of huge restricted areas by extremely shallow water sheets, much of them only tens of centimetres deep. Extensive evaporite deposits and muddy carbonates, mostly peloid mudstones and packstones, were deposited in these evaporitic seaways. The laminated carbonate mudstone and sulphate deposits of the Oncala Group show some resemblances to these ancient deposits, in that they were developed in broad, shallow, confined areas with high salinities, and muddy/ peloidal carbonates and evaporites were deposited (Quijada et al., 2013).

\subsection{Lateral and vertical evolution}

In addition to the identification of the four main stratigraphic intervals (Figs. 4, 6), the analysis of the lateral and vertical facies changes of the Oncala Group allows the recognition of very gradual retrogradational and progradational trends of the siliciclastic deposits and the carbonate-evaporitic deposits. Stratigraphic interval A (Figs. 4, 6) is characterized by the gradual progradation of siliciclastic sediments over carbonate-evaporitic deposits (Figs. 4, 6). The maximum progradation of the siliciclastic sediments marks the start of the stratigraphic interval B (Figs. 3B, 4, 6). A general, gradual retrogradational trend is then observed in this interval.

The important retrogradation of the siliciclastic facies that occurred at the base of the interval $\mathrm{C}$ triggered a westward migration of the siliciclastic deposits, and the concurrent expansion of carbonate-evaporitic deposits over most of the basin (interval C, Fig. 4, 6). Moreover, the carbonate-evaporitic deposits of interval $\mathrm{C}$ contain smaller amounts of evaporites, which likely indicate shorter periods of confined conditions in the carbonatesulphate water bodies than in the lower intervals $\mathrm{A}$ and B. In the central areas of the basin (Yn, Figs. 3B, 4, 6, 7A), siliciclastic facies of the lower part of the interval $\mathrm{C}$ are interbedded with the carbonate-evaporitic deposits. The siliciclastic content gradually decreases upwards while the content of carbonate-evaporitic deposits increases until they occupy the entire basin in the upper part of interval C (Figs. 3B, 4, 6). This suggests that the retrogradational trend recorded in interval $\mathrm{B}$ continued throughout interval C.

Interval D (Fig. 4) is characterized in all the stratigraphic sections by laminated carbonate-evaporitic deposits containing larger fossil content, lower proportion of evaporites, black shales, abundant mudcracks, ripples, centimetre-size pseudomorphs after gypsum, and tepees. This demonstrates more abundant freshwater and siliciclastic discharges into the water bodies than in the underlying sediments, indicative of a progradational trend.

Gómez-Fernández (1992) interpreted that the succession of the westernmost area of the basin (Mo, Fig. 4) was laterally related only with the upper carbonate-evaporitic deposits (i.e. intervals $\mathrm{C}$ and $\mathrm{D}$ of this study). However, this author describes a gradual vertical change in the stratigraphic log of Montenegro from deposits of braided rivers to meandering rivers interbedded with rare carbonate layers, and finally to black carbonate deposits. We suggest that this retrogradational trend is rather related to the retrogradational trend recorded in the stratigraphic intervals B and C (Fig. 4). The occurrence of the carbonate layers is likely related with the important retrogradation that marks the beginning of the interval $\mathrm{C}$. 


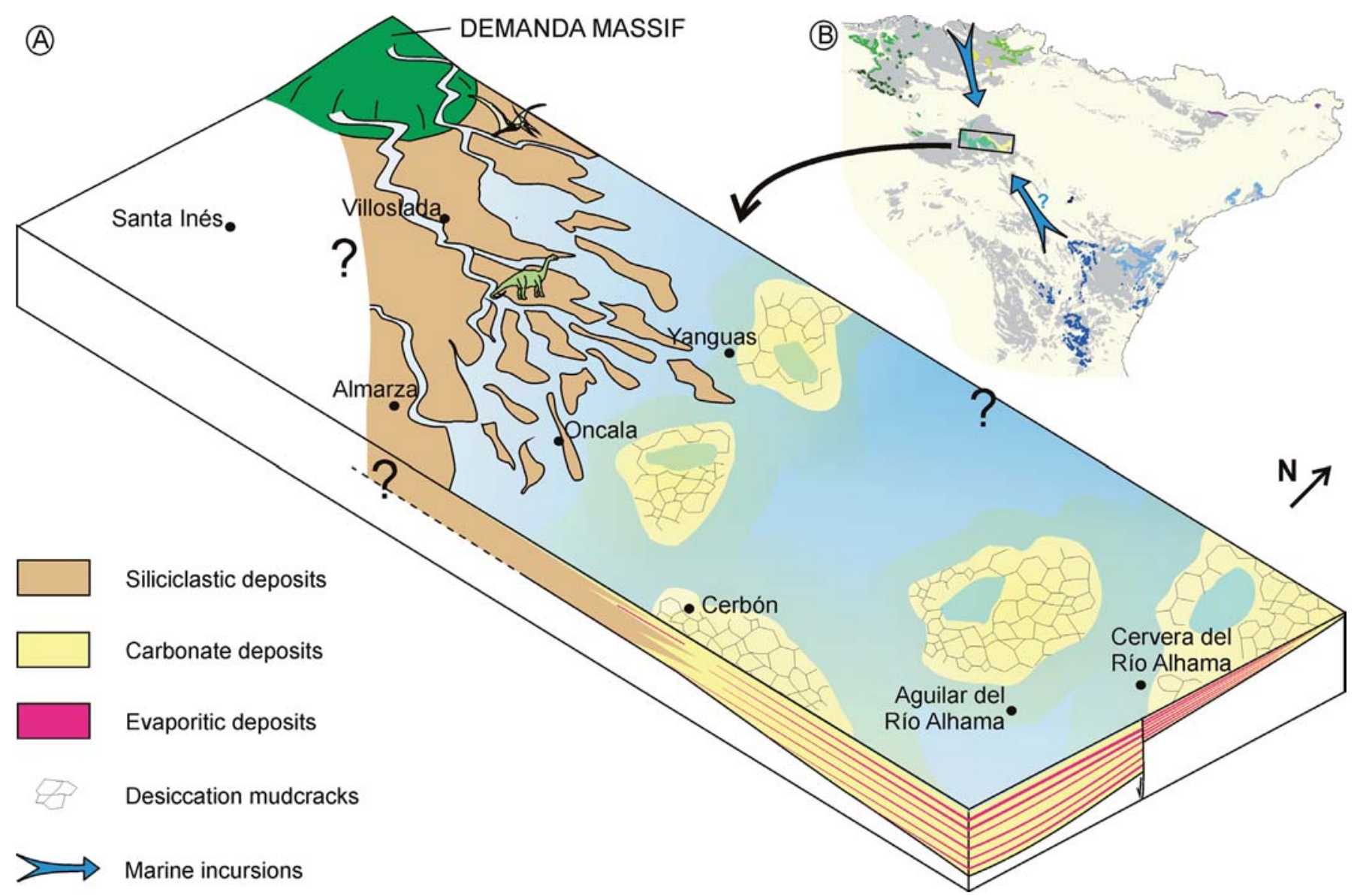

Fig. 10.- A- Paleogeographic reconstruction of the eastern Cameros Basin in Berriasian times (during deposition of the lower to middle part of the third stratigraphic interval of the Oncala Group). Siliciclastic tidal flats developed in western areas of the basin, and shallow, coastal, carbonatesulphate water bodies formed in eastern areas of the basin. The shallow depositional depth and the very low gradients of these water bodies caused the occasional exposure of large areas of them. B- Synthetic map showing the location of the Berriasian deposits of the Iberian Peninsula (see Fig. 5 for more detail). The blue arrows mark the probable marine influence in the Cameros Basin from the Basque-Cantabrian Basin and the possible marine influence from the Iberian Basin.

Fig. 10.- A- Reconstrucción paleogeográfica de la Cuenca de Cameros oriental durante el Berriasiense (durante el depósito de la parte inferior a media del tercer intervalo estratigráfico del Grupo Oncala). En las zonas occidentales de la cuenca se formaron llanuras mareales siliciclásticas y en las zonas orientales se formaron cuerpos de agua costeros someros de composición carbonático-evaporítica. La poca profundidad y bajos gradientes topográficos de estos cuerpos de agua causaban que extensas zonas quedaran ocasionalmente expuestas. B- Mapa sintético que muestra la localización de los depósitos berriasienses de la Península Ibérica (ver Fig. 5 para más detalle). Las flechas azules marcan la probable influencia marina en la Cuenca de Cameros desde la Cuenca Vasco-Cantábrica y la posible influencia desde la Cuenca Ibérica.

Another important issue is the sharp change in thickness, from $2500 \mathrm{~m}$ to $700 \mathrm{~m}$ of sediments, between the sections of Aguilar and Cervera ( $\mathrm{Ag}$ and Ce in Fig. 4), i.e. a difference of $1800 \mathrm{~m}$ between areas that are less than $10 \mathrm{~km}$ apart. An important fault and several tectonic structures separate now these two areas (Fig. 3B). It is suggested that this fracture zone was active during deposition of the Oncala Group, as was previously proposed by Gómez-Fernández and Meléndez (1994a), and it was afterwards reactivated during the Alpine Orogeny. Moreover, in the easternmost area of the basin the same retrogradational and progradational trends as in the adjacent area are recognized, which suggests that the four stratigraphic intervals of the Oncala Group were also recorded in this area of reduced thickness. These consid- erations indicate that the syn-sedimentary fracture zone was active during the deposition of the entire Oncala succession. The lower accommodation rate in the area of Cervera relatively to the area of Aguilar, however, did not cause major facies changes between both areas, but is responsible for more common subaerial exposure in the area of Cervera (Fig. 4).

\subsection{Lithostratigraphic revision of the Oncala Group}

The lithostratigraphic units proposed by other authors for the Oncala Group are revised considering the updated stratigraphic data (Fig. 6). Although Gómez-Fernández (1992) and Gómez-Fernández and Meléndez (1994b) based their subdivisions of the Oncala Group on the pres- 
ence of an unconformity (see section 4 and Fig. 6), we have not recognized any unconformity within the Oncala Group, but gradual vertical and lateral facies changes, as discussed above (Figs. 3B, 4, 6). As a consequence, we consider that subdivisions based on lithostratigraphic considerations, similar to those proposed by Guiraud and Seguret (1985, see section 4 and Fig. 6), are more suitable. In agreement with Guiraud and Seguret (1985), the western siliciclastic deposits of the Oncala Group are grouped as the Huérteles Formation; the lower carbonate-evaporitic deposits of intervals A and B, as the Aguilar del Río Alhama Formation; and the upper carbonate-evaporitic deposits of intervals $\mathrm{C}$ and $\mathrm{D}$, as the Valdeprado Formation (Fig. 6). Nevertheless, in contrast to the original definition of Guiraud and Seguret (1985), we interpret that the Valdeprado Formation is also laterally related with siliciclastic deposits towards the west (Figs. 3B, 4, 6, 7A). We also establish that the lower limit of the Valdeprado Formation in the central areas of the basin (Yn, Fig. 4) is marked by the presence of parallel-laminated carbonate-deposits of stratigraphic interval $\mathrm{C}$, instead of by the disappearance of sandstone bodies, as was interpreted by Guiraud and Seguret (1985), Gómez-Fernández (1992), and GómezFernández and Meléndez (1994b). Although Guiraud and Seguret (1985) named the lower carbonate-evaporitic deposits Aguilar Formation, we have enlarged this name to Aguilar del Río Alhama Formation to avoid misunderstanding with the Tithonian-Berriasian Aguilar Formation of the Basque-Cantabrian Basin (Hernández et al., 1999).

\subsection{Comparison with other Berriasian successions of NE Iberia}

Once established that the Berriasian deposits of the Cameros Basin were formed in coastal environments, it remains the question of the provenance of the marine waters. To answer that question the deposits of the Oncala Group are compared with those of the neighbouring Basque-Cantabrian, Iberian, and Pyrenean Basins, all of which containing open marine sediments.

Berriasian deposits of the Basque-Cantabrian Basin display different facies associations from western to eastern areas (summarized in Fig. 5). The TithonianBerriasian succession of the Cantabrian graben, in the western Basque-Cantabrian Basin (Fig. 5), is made up of continental to shallow-marine deposits (Pujalte, 1982; Pujalte et al., 2004; and references therein). Continental deposits, including fluvial sandstone and mudstone and lacustrine-palustrine carbonates and evaporites, are more extensive in the lowermost part of the succession, being best developed in southwesternmost areas (García de Cortázar and Pujalte, 1982; Lanaja and Navarro, 1987; Pujalte et al., 2004; and references therein). Sediments of the middle part of the succession, which consist of siliciclastic and carbonate mudstones and less abundant sandstones, are interpreted as formed in shallow brackish lagoons (Pujalte, 1982; García de Cortázar and Pujalte, 1982). The overlying sediments, made up of sandstones, sandy limestones, and mudstones, are interpreted as deposited in broad tidal flats and channels, and they form a transgressive-regressive cycle (Pujalte, 1982; García de Cortázar and Pujalte, 1982). Continental deposits then prograde over the tidal flat sediments in the uppermost part of the Berriasian succession.

In the Bilbao anticlinorium, in the central area of the Basque-Cantabrian Basin (Fig. 5), Lower Cretaceous thick successions containing interbedded black shales, evaporites (anhydrite and gypsum, and also halite in Cegama-1 and Aitzgorri-1 wells), and minor sandstones and limestones, have been drilled in oil exploration wells (Lanaja and Navarro, 1987; Ábalos et al., 2008; Iríbar and Ábalos, 2011). Unfortunately, the low biostratigraphic resolution of the fossils in these deposits makes them difficult to date. Thus, Sánchez-Ferrer (1991) tentatively attributed them a Late Jurassic-Valanginian age, whereas Ábalos et al. (2008) lithologically correlated them with the earliest sediments of the Villaro Formation, whose age is also uncertain (Berriasian for Ramírez del Pozo, 1969; upper Berriasian-early Valanginian for García-Garmilla, 1989; upper Valanginian for Pujalte et al., 2004). Whatever the case, sulphur isotope compositions of the sulphates range between 17.4 and $23.7 \% \mathrm{o}_{\mathrm{V}-\mathrm{CDT}}$ (mean value $=19.6 \% \mathrm{o}_{\mathrm{V}-\mathrm{CDT}}$, Ábalos et al., 2008; Iribar and Ábalos, 2011), which is very similar to the composition of the gypsum of the Oncala Group (mean value $=18.2 \%_{\mathrm{V}-\mathrm{CDT}}$, Alonso-Azcárate et al. 2006). In the northern part of the Bilbao region (Fig. 5), oil exploration wells discovered shallow marine limestones in a stratigraphic position equivalent to the described Berriasian deposits of the Basque-Cantabrian Basin. This suggests that a connection with the open sea existed in this northern area (Rosales et al., 2002b).

Eastern areas of the Basque-Cantabrian Basin (Fig. 5) contain black limestones with pellets, serpulids, gastropods, and bivalves, interpreted as deposited in restricted marine environments (Pujalte, 1982). These sediments thin eastwards, eventually disappearing in the Basque massifs, which were paleogeographic highs at that moment (Soler and José, 1972; Rosales et al., 2002a).

Berriasian deposits of the Iberian Basin are present in the South Iberian sub-basin, Maestrat sub-basin, and Catalonian Coastal Ranges, and display also important lateral changes (Aurell et al., 1994; Bádenas et al., 2004; Mas and Salas, 2002; Mas et al., 2004; and references therein). In the western areas of the Iberian Basin (Fig. 5), siliciclastic tidal flats incised by meandering tidal channels were developed (Mas et al., 1984; Aurell et 
al., 1994; Cobos et al., 2010). They pass southwards to carbonate mudstones to wackestones formed in a subtidal lagoon. In eastern areas of the Iberian Basin (Fig. 5), carbonate tidal flats and fringing oolitic-bioclastic shoals were developed (Salas, 1989; Bádenas et al., 2004). The lateral relationship between the carbonate and siliciclastic tidal flats is gradual, and both grade southeastwards (Fig. 5) into hemipelagic Calpionella limestones (Salas, 1989; Aurell et al., 1994). Moreover, thinner (up to $70 \mathrm{~m}$ thick), Tithonian-Berriasian, marine-influenced siliciclastic mudstones and sandstones (Ipas et al., 2007) have been described in the Iberian Basin in the province of Zaragoza (Villanueva de Huerva and Aguilón sectors, Fig. 5).

Berriasian deposits of the Pyrenees are present in the Organya Basin and Figueres-Montgrí area (Fig. 5), and consist of a succession of marls, limestones, silty sandstones, and carbonaceous silty limestones. This succession shows a shallowing-up evolution, from pelagic deposits at the base to inner ramp sediments in the middle part, and finally, to lagoonal deposits in the upper part (Berástegui et al , 2002; Robador and García-Senz, 2004).

The sedimentary record of Berriasian times in Iberia shows that open marine areas were located in northernmost Basque-Cantabrian Basin, southeasternmost Iberian Basin, and the Pyrenees. The Oncala Group display strong similarities with the deposits of the Basque-Cantabrian Basin, such as the presence of broad, brackish shallow areas, or the occurrence of siliciclastic sediments (frequently tidal) in western areas of the basin and carbonate facies in eastern areas. Moreover, evaporites may have also been formed in the Bilbao region of the Basque-Cantabrian Ba$\sin$ at Berriasian times. Although their age is uncertain, the similar sulphur isotope compositions and sedimentological features of the evaporitic deposits of both basins make us think that at least part of the evaporitic deposits of the Basque-Cantabrian Basin could be correlatable with those in the Oncala Group. If this hypothesis is right, the strong similarities in the sulphur isotope compositions of the sulphates of both basins would suggest that the sulphate source was the same for both areas. Furthermore, these $\delta^{34} \mathrm{~S}$ compositions between 17.4 and $23.7 \%$ are similar to the sulphur isotope composition of lowermost Cretaceous seawater (cf. Paytan et al., 2004; Paytan and Gray, 2012), and strongly different from $\delta^{34} \mathrm{~S}$ compositions around $14 \%$ of the Triassic evaporites of the Basque-Cantabrian and Cameros Basins (Alonso-Azcárate et al., 2006; Iribar and Ábalos, 2011), which were also proposed as a sulphate source. Thus, the sulphur isotope compositions indicate that the more plausible sulphate source in both the Basque-Cantabrian and Cameros Basin was probably Lower Cretaceous seawater. All these similarities plus the proximity of both basins suggest that the Cameros Ba- sin was connected with coastal and marine areas of the Basque-Cantabrian Basin during Berriasian times (Fig. 10B). This paleogeographic affinity of the sediments of the Cameros area with Boreal marine areas of the BasqueCantabrian Basin is not exclusive of the Oncala Group; in fact, during the late Kimmeridgian the Boreal shoreline was much closer to the Cameros area than the Tethys shoreline (Benito et al., 2005). Unfortunately, the presence of the Tertiary Ebro Basin between the Cameros Basin and the Basque Cantabrian Basin impedes establishing the exact location of the connection between these basins during Berriasian times.

An attempt of correlating the progradational-retrogradational trends observed in the Oncala Group and in the Berriasian sediments of the Cantabrian graben has been carried out. In both basins a general retrogradational trend is observed in most of the succession. In the Cantabrian graben continental deposits in the lower part pass gradually to tidal flat deposits (Pujalte, 1982; García de Cortázar and Pujalte, 1982; Pujalte et al., 2004; and references therein). In the Oncala Group the siliciclastic system migrated progressively landwards and carbonatesulphate water bodies developed over most of the basin. It is interpreted that both retrogradational trends could be related to the same relative sea-level rise episode, which can be tentatively correlated with the transgressive cycle that occurred from lower to middle Berriasian in Boreal and Tethyan European basins (Hardenbol et al., 1998; Ogg et al., 2008; Ogg et al., 2012). Berriasian successions in both basins recorded a progradational trend in the uppermost part, which caused the progradation of fluvial sediments over tidal deposits in the Cantabrian graben (Pujalte, 1982; Pujalte et al., 2004), and more abundant siliciclastic and freshwater discharges in the Oncala Group. This progradational trend could be related with the regressive cycle that occurred during the upper Berriasian in the European basins (Hardenbol et al., 1998; Ogg et al., 2008; Ogg et al., 2012).

Apart from the connection with the Basque-Cantabrian Basin, a southeast connection of the Cameros Basin with the Iberian Basin at Berriasian times cannot be excluded (Fig. 10B). The development of tidal flats in the Iberian Basin, and the presence of basins with marine-influenced deposits in an intermediate position between the South Iberian and Maestrat Basins and the Cameros Basin, such as the Villanueva de Huerva and Aguilón sectors (Fig. 5), lead to interpret that a connection of the Cameros Basin and the Tethys Sea could have existed. The relationship between the Cameros and Pyrenean Basins cannot be established because a major stratigraphic gap exists in the Berriasian sedimentary record of the Pyrenean Basin. However, it is documented that a paleogeographic high, 
the so-called Ebro Massif, separated both basins (e.g. Ziegler, 1988; Salas et al., 2001; Mas et al., 2004).

\section{Conclusions}

The sedimentological analysis of the Oncala Group indicates that the eastern sector of the Cameros Basin during Berriasian times was occupied by a fluvial system in the westernmost area; broad, siliciclastic tidal flats in the western to central areas; and extensive, coastal, shallow, carbonate-sulphate water bodies, which received marine seawater input, in the central to eastern areas. This new interpretation differs from previous paleoenvironmental reconstructions, which ascribed an exclusively continental origin to these deposits.

The analysis of the lateral and vertical evolution of the Oncala Group allows the recognition of very gradual progradational and retrogradational trends of the siliciclastic deposits and the carbonate-evaporitic deposits. The Oncala Group shows a general retrogradational trend in most of the succession, which caused the gradual migration of the siliciclastic deposits westwards and the progressive spreading of the carbonate-evaporitic deposits over most of the basin. This interpretation implies that the development of carbonate-evaporitic deposits over large areas of the basin in the middle to upper part of the Oncala Group is not related with an unconformity within the unit, as was previously interpreted, but with gradual, vertical and lateral facies changes.

The sharp change in thicknesses between the easternmost area of the basin, close to the town of Cervera del Río Alhama (up to $720 \mathrm{~m}$ of sediments), and the adjacent area, close to the town of Aguilar del Río Alhama (up to $2500 \mathrm{~m}$ of sediments), is probably related with a syn-sedimentary fracture zone that was active during the deposition of the entire Oncala Group.

The development of broad tidal flats and coastal, shallow water bodies in the Oncala Group suggest that a wide, shallow, coastal embayment was developed in the Cameros Basin at Berriasian times. This new interpretation makes necessary to revise the paleogeographic reconstructions of this area of Iberia during Berriasian times. Comparison of the deposits of the Oncala Group with Berriasian deposits of adjacent basins strongly suggests that the Cameros Basin was connected with transitional and marine areas of the Basque-Cantabrian Basin, in which similar facies associations were deposited and a similar vertical evolution is evident. Additionally, a connection with the southern Iberian Basins cannot be excluded.

\section{Acknowledgements}

This work was funded by the Spanish DIGICYT projects CGL2008-01648/BTE and CGL2011-22709, the "Sedimentary Basin Analysis" Research Group of the Complutense University of Madrid-Madrid Community and a Spanish Department of Education FPU scholarship. The authors are very grateful to B. Tessier and V. Pujalte for their thoughtful and thorough reviews, and the editors J. López-Gómez and J. Martín-Chivelet for their kind support. We thank S. Lugli and F. Ortí for helpful discussion about the sulphur isotope compositions, S. Sacristán for providing information about the location of Berriasian outcrops in western Cameros Basin and help during field work, and A. Baza for help in the preparation of thin sections. We thank also the staff of the IGEO and the Department of Stratigraphy of the Complutense University of Madrid for their technical support, especially to B. Moral, G. Herrero, and J.C. Salamanca for preparation of thin sections, V. López for help with GIS, and L. Donadeo for bibliographic support.

\section{References}

Ábalos, B., Alkorta, A., Iríbar, V. (2008): Geological and isotopic constraints on the structure of the Bilbao anticlinorium (Basque-Cantabrian basin, North Spain). Journal of Structural Geology 30, 13541367. doi:10.1016/j.jsg.2008.07.008

Alonso, A., Mas, R. (1990): El Jurásico superior marino en el sector Demanda-Cameros. La Rioja-Soria. Cuadernos de Geología Ibérica 14, 173-198.

Alonso, A., Meléndez, N., Mas, R. (1986-1987): Los arrecifes coralinos del Malm en la Sierra de los Cameros (La Rioja, España). Acta Geológica Hispánica 21-22, 296-306.

Alonso-Azcárate, J., Bottrell, S. H., Mas, R. (2006): Synsedimentary versus metamorphic control of $\mathrm{S}, \mathrm{O}$ and $\mathrm{Sr}$ isotopic compositions in gypsum evaporites from the Cameros Basin, Spain. Chemical Geology 234, 46-57. doi:10.1016/j.chemgeo.2006.04.004

Arribas, J., Alonso, A., Mas, R., Tortosa, A., Rodas, M., Barrenechea, J.F., Alonso-Azcarate, J., Artigas, R. (2003): Sandstone petrography of continental depositional sequences of an intraplate rift basin: Western Cameros Basin (North Spain). Journal of Sedimentary Research 73 (2), 309-327. doi:10.1306/082602730309

Aurell, M., Mas, R., Meléndez, A., Salas, R. (1994): El tránsito JurásicoCretácico en la Cordillera Ibérica: relación tectónica-sedimentación y evolución paleogeográfica. Cuadernos de Geología Ibérica 18, 369396.

Aurell, M., Robles, S., Bádenas, B., Rosales, I., Quesada, S., Meléndez, G., García-Ramos, J.C. (2003): Transgressive-regressive cycles and Jurassic palaeogeography of northeast Iberia. Sedimentary Geology 162, 239-271. doi:10.1016/S0037-0738(03)00154-4

Bádenas, B., Salas, R., Aurell, M. (2004): Three orders of regional sealevel changes control facies and stacking patterns of shallow platform carbonates in the Maestrat Basin (Tithonian-Berriasian, NE Spain). International Journal of Earth Sciences: Geologische Rundschau 93, 144-162. doi:10.1007/s00531-003-0367-2

Benito, M.I., Lohmann, K.C., Mas, R. (2006): Micro-sized dolomite inclusions in ferroan calcite cements developed during burial diagenesis of Kimmeridgian reefs, Northern Iberian Basin, Spain. Journal of 
Sedimentary Research 76, 472-482. doi: 10.2110/jsr.2006.042

Benito, M. I., Mas, R. (2006): Sedimentary evolution of the Torrecilla Reef Complex in response to tectonically forced regression (Early Kimmeridgian, Northern Spain). Sedimentary Geology 183, 31-49. doi:10.1016/j.sedgeo.2005.09.007

Berástegui, X., Caus, E., Puig, C. (2002): Lower Cretaceous of the Pyrenees. In: W. Gibbons, T. Moreno (eds.), The Geology of Spain. The Geological Society, London, pp. 267-270.

Brown, K.J., Pasternack, G.B. (2004): The geomorphic dynamics and environmental history of an upper deltaic floodplain tract in the Sacramento-San Joaquin Delta, California, USA. Earth Surface Processes and Landforms 29, 1235-1258. doi:10.1002/esp.1088

Clemente, P. (2010): Review of the Upper Jurassic-Lower Cretaceous Stratigraphy in Western Cameros basin, Northern Spain. Revista de la Sociedad Geológica de España 23 (3-4), 101-143.

Cobos, A., Royo-Torres, R., Luque, L., Alcalá, L., Mampel, L. (2010): An Iberian stegosaurs paradise: The Villar del Arzobispo Formation (Tithonian-Berriasian) in Teruel (Spain). Palaeogeography, Palaeoclimatology, Palaeoecology 293, 223-236. doi:10.1016/j.palaeo.2010.05.024

Dalrymple, R.W., Choi, K. (2007): Morphologic and facies trends through the fluvial-marine transition in tide-dominated depositional systems: A schematic framework for environmental and sequencestratigraphic interpretation. Earth-Science Reviews 81, 135-174. doi:10.1016/j.earscirev.2006.10.002

Dickson, J.A.D. (1966): Carbonate identification and genesis as revealed by staining. Journal of Sedimentary Petrology 36, 491-505.

Doublet, S. (2004): Contrôles tectonique et climatique de l'enregistrement stratigraphique dans un basin continental de rift: le bassin de Cameros. Unpublished Ph. D. Thesis, Université de Dijon, 494 p.

Elliott, L.A., Warren, J.K. (1989): Stratigraphy and Depositional Environment of Lower San Andres Formation in Subsurface and Equivalent Outcrops: Chaves, Lincoln, and Roosevelt Counties, New Mexico. AAPG Bulletin 73, 1307-1325.

García de Cortázar, A., Pujalte, V. (1982): Litoestratigrafía y facies del Grupo Cabuérniga (Malm-Valanginiense inferior?) al S de CantabriaNE de Palencia. Cuadernos de Geología Ibérica 8, 5-21.

García-Garmilla, F. (1989): The "wealden" of central Basque-Cantabrian región (Villaro Formation): Petrology and stratigraphic correlation with the Western formations. Kobie 18, 35-49.

Gómez-Fernández, J.C. (1992): Análisis de la Cuenca sedimentaria de los Cameros durante sus etapas iniciales de relleno en relación con su evolución paleogeográfica. Unpublished Ph. D. Thesis, Universidad Complutense de Madrid, Madrid, 343 p.

Gómez-Fernández, J. C., Meléndez, N. (1994a): Climatic control on Lower Cretaceous sedimentation in a playa-lake system of a tectonically active basin (Huérteles Alloformation, Eastern Cameros Basin, North-Central Spain). Journal of Paleolimnology 11, 91-107. doi:10.1007/BF00683272

Gómez-Fernández, J.C., Meléndez, N. (1994b): Estratigrafía de la "Cuenca de los Cameros" (Cordillera Ibérica Noroccidental, N de España) durante el tránsito Jurásico-Cretácico. Revista de la Sociedad Geológica de España 7 (1-2), 121-139.

Guimerà, J., Alonso, A., Mas, R. (1995): Inversion of an extensionalramp basin by a newly formed thrust: the Cameros Basin (N Spain). In: J.G. Buchanan, P.G. Buchanan (eds.), Basin Inversion. Geological Society of London Special Publication 88, pp. 433-453.

Guiraud, M. (1983): Evolution tectono-sedimentaire du Bassin Wealdien (Crétacé Inferieur) en relais de decrochements de Logroño-Soria ( $N$-W Espagne). Unpublished $\mathrm{Ph}$. D. Thesis, Université du Languedoc, Montpellier, $184 \mathrm{p}$.

Guiraud, M., Seguret, M. (1985): A releasing solitary overstep model for the Late Jurassic-Early Cretaceous (Wealdian) Soria strike-slip basin (Northern Spain). In: N. Christie-Blick, K.T. Biddle (eds.), Strike-Slip
Deformation, Basin Formation, and Sedimentation. Society of Economic Paleontologists and Mineralogists Special Publication 37, pp. 159-175.

Hardenbol, J., Thierry, J., Farley, M.N., Jacquin, T., de Graciansky, P.C., Vail, P.R. (1998): Mesozoic and Cenozoic sequence chronostratigraphic framework of European basins. In: P.-C. de Graciansky, J. Hardenbol, T. Jacquin, P.R. Vail (eds.), Mesozoic and Cenozoic Sequence Stratigraphy of European Basins. Society of Economic Paleontologists and Mineralogists Special Publication 60, pp. 3-13, charts $1-8$.

Hernández, J.M., Pujalte, V., Robles, S., Martín-Closas, C. (1999): División estratigráfica genética del Grupo Campóo (Malm-Cretácico Inferior, SW Cuenca Vascocantábrica). Revista de la Sociedad Geológica de España 11(3-4), 377-396.

Hernández-Samaniego, A., Ramírez, J.J., Olivé, A., Álvaro, M., Ramírez del Pozo, J., Aguilar, M.J., Meléndez, A. (1990): Hoja geológica num. 242 (Munilla). Mapa Geológico de España E. 1:50.000. I.G.M.E., Madrid.

Inam, A. Clift, P.D., Giosan, L., Rashid Tabrez, A., Tahir, M., Rabbani, M.M., Danish, M. (2007): The Geographic, Geological and Oceanographic Setting of the Indus River. In: A. Gupta (ed.), Large Rivers: Geomorphology and Management. John Wiley and Sons, Chichester, pp. 333-346.

Ipas, J., Aurell, M., Bádenas, B., Canudo, J.I., Llesa, C., Mas, J.R., Soria, A.R. (2007): Caracterización de la Formación Villar del Arzobispo al sur de Zaragoza (Titónico, Cordillera Ibérica). Geogaceta 41, 111-114.

Iribar, V., Ábalos, B. (2011): The geochemical and isotopic record of evaporite recycling in spas and salterns of the Basque Cantabrian basin, Spain. Applied Geochemistry 26, 1315-1329. doi:10.1016/j.apgeochem.2011.05.005

John, J. W. St., Jr., Eby, D.E. (1978): Peritidal carbonates and evidence for vanished evaporites in the lower Ordovician Cool Creek Formation-Arbuckle Mountains, Oklahoma. Transactions of the Gulf Coast Association of Geological Societies 28, 589-599.

Lanaja, J.M., Navarro, A. (1987): Contribución de la exploración petrolifera al conocimiento de la Geología de España. I.G.M.E., Madrid, $465 \mathrm{p}$.

Martín-Closas, C., Alonso, A. (1998): Estratigrafía y bioestratigrafía (Charophyta) del Cretácico inferior en el sector occidental de la Cuenca de Cameros (Cordillera Ibérica). Revista de la Sociedad Geológica de España 11(3-4), 253-270.

Mas, R., Salas, R. (2002): Lower Cretaceous of the Iberian basin. In: W. Gibbons, T. Moreno (eds.), The Geology of Spain. The Geological Society, London, pp. 284-288.

Mas, R., Alonso, A., Meléndez, N. (1984): La Formación Villar del Arzobispo: un ejemplo de llanuras de marea siliciclásticas asociadas a plataformas carbonatadas. Jurásico terminal (NW. de Valencia y E. de Cuenca). Publicaciones de Geología (Universidad Autónoma de Barcelona) 20, 175-188.

Mas, R., Alonso, A., Guimerà, J. (1993): Evolución tectonosedimentaria de una cuenca extensional intraplaca: la cuenca finijurásica- eocretácica de Los Cameros (La Rioja- Soria). Revista de la Sociedad Geológica de España 6 (3-4), 129-144.

Mas, R., Benito, M.I., Arribas, J., Serrano, A., Guimerà, J., Alonso, A., Alonso-Azcarate, J. (2002): La Cuenca de Cameros: desde la extensión finijurásica-eocretácica a la inversión terciaria - implicaciones en la exploración de hidrocarburos. Zubia 14, 9-64.

Mas, R., García, A., Salas, R., Meléndez, A., Alonso, A., Aurell, M., Bádenas, B., Benito, M.I., Carenas, B., García-Hidalgo, J.F., Gil, J., Segura, M. (2004): Segunda fase de rifting: Jurásico SuperiorCretácico Inferior. In: J.A. Vera (ed.), Geología de España. SGEIGME, Madrid, pp. 503-510.

Mas, R., Benito, M.I., Arribas, J., Alonso, A., Arribas, M.E., Lohm- 
ann, K.C., González-Acebrón, L., Hernán, J., Quijada, E., Suarez, P., Omodeo, S. (2011): Evolution of an intra-plate rift basin: the Latest Jurassic-Early Cretaceous Cameros Basin (Northwest Iberian Ranges, North Spain). In: C. Arenas, L. Pomar, F. Colombo (eds.), Post-Meeting Field trips $28^{\text {th }}$ IAS Meeting, Zaragoza. Geo-guías 8, pp. 117-154.

Meléndez, N., Gómez-Fernández (2000): Continental Deposits of the Eastern Cameros Basin (Northern Spain) During Tithonian-Berriasian Time. In: E.H. Gierlowski-Kordesch, K.R. Kelts (eds.), Lake basins through space and time. AAPG Studies in Geology 6, pp. 263-278.

Ogg, J.G., Ogg, G., Gradstein, F.M. (2008): The Concise geologic Time Scale. Cambridge University Press, Cambridge, $177 \mathrm{p}$.

Ogg, J.G., Hinnov, L.A., Huang, C. (2012): Cretaceous. In: F.M. Gradstein, J.G. Ogg, M.D. Schmitz, G. M. Ogg (eds.), The geologic time scale 2012. Elsevier, Amsterdam, pp. 793-853. doi:10.1016/B978-0444-59425-9.00027-5

Ortí, F. (2010): Evaporitas: introducción a la sedimentología evaporítica. In: A. Arche (ed.), Sedimentología. Del proceso físico a la cuenca sedimentaria. Consejo Superior de Investigaciones Científicas, Madrid, pp. 675-769.

Paytan, A., Gray, E.T. (2012): Sulfur Isotope Stratigraphy. In: F.M. Gradstein, J.G. Ogg, M.D. Schmitz, G. M. Ogg (eds.), The geologic time scale 2012. Elsevier, Amsterdam, pp. 167-180. doi:10.1016/ B978-0-444-59425-9.00009-3

Paytan, A., Kastner, M., Campbell, D., Thiemens, M.H. (2004): Seawater Sulfur Isotope Fluctuations in the Cretaceous. Science 304, 16631665. doi: $10.1126 /$ science. 1095258

Pujalte, V. (1982): Tránsito Jurásico-Cretácico, Berriasiense, Valanginiense, Hauteriviense y Barremiense. In: A. García (ed.), El Cretácico de España. Universidad Complutense de Madrid, Madrid, pp. 51-63.

Pujalte, V., Robles, S., Hernández, J.M. (1996): La sedimentación continental del Grupo Campóo (Malm-Cretácico basal de Cantabria, Burgos y Palencia): testimonio de un reajuste hidrográfico al inicio de una fase rift. Cuadernos de Geología Ibérica 21, 227-251.

Pujalte, V., Robles, S., García-Ramos, J.C., Hernández, J.M. (2004): El Malm-Barremiense no marinos de la Cordillera Cantábrica. In: J.A. Vera (ed.), Geología de España. SGE-IGME, Madrid, pp. 288-291.

Quijada, I.E. (2009): Caracterización sedimentológica de los depósitos carbonático-evaporíticos de edad Berriasiense (Grupo Oncala) en el sector de Aguilar del Río Alhama. Cuenca de Cameros Oriental (NO de la Cordillera Ibérica). Unpublished Master's Thesis, Universidad Complutense de Madrid, 54 p.

Quijada, I.E., Lugli, S., Suarez-Gonzalez, P., Ortí, F., Benito, M.I., Mas, R. (2010a): Sedimentary features preserved in the deformed Berriasian sulphate-carbonate deposits of the Oncala Group, Cameros Basin (Northern Spain). Abstracts GEOSED 2010, Torino, pp. 58-59.

Quijada, I.E., Suarez-Gonzalez, P., Benito, M.I., Mas, J.R., Alonso, A. (2010b): Un ejemplo de llanura fluvio-deltaica influenciada por las mareas: el yacimiento de icnitas de Serrantes (Grupo Oncala, Berriasiense, Cuenca de Cameros, N. de España). Geogaceta 49, 15-19.

Quijada, I.E., Suarez-Gonzalez, P., Benito, M.I., Mas, R. (2012): An atypical mechanism of carbonate brecciation caused by tectonism in carbonate-sulfate deposits: evidence from the Oncala Gr (Berriasian, N Spain). Abstracts 29th IAS Meeting of Sedimentology 2012, Schladming, p. 317.

Quijada, I. E., Suarez-Gonzalez, P., Benito, M.I., Mas, R. (2013): Depositional depth of laminated carbonate deposits: insights from the Lower Cretaceous Valdeprado Formation (Cameros Basin, northern Spain). Journal of Sedimentary Research 83, 241-257. doi: 10.2110/ jsr.2013.23

Quijada, I.E., Suarez-Gonzalez, P., Benito, M.I., Mas, R. (2014): Tidal versus continental sandy-muddy flat deposits: evidence from the Oncala Group (Early Cretaceous, N Spain). In: B. Tessier, J.Y. Reynaud (eds.). International Association of Sedimentologists Special Publica- tion 48 , in press.

Raharimahefa, T., Kusky, T.M. (2010): Environmental Monitoring of Bombetoka Bay and the Betsiboka Estuary, Madagascar, Using Multi-temporal Satellite Data. Journal of Earth Science 21(2), 210-226. doi: 10.1007/s12583-010-0019-y

Ramírez del Pozo, J. (1969): Sintesis estratigráfica y micropaleontológica de las facies Purbeckiense y Wealdense del Norte de España. CEPSA, Madrid, $68 \mathrm{p}$.

Robador, A., García-Senz, J. (2004): El Cretácico Inferior de la vertiente surpirenaica. In: J.A. Vera (ed.), Geología de España. SGE-IGME, Madrid, pp. 285-288.

Rosales, I., Gräfe, K.-U., Robles, S., Quesada, S., Floquet, M. (2002a): The Basque-Cantabrian Basin. In: W. Gibbons, T. Moreno (eds.), The Geology of Spain. The Geological Society, London, pp. 272-274.

Rosales, I., Robles, S., Quesada S. (2002b): Early Cretaceous of the Basque-Cantabrian Basin. In: W. Gibbons, T. Moreno (eds.), The Geology of Spain. The Geological Society, London, pp. 274-281.

Salas, R. (1989): Evolución estratigráfica secuencial y tipos de plataformas de carbonatos del intervalo Oxfordiense-Berriasiense en las cordilleras ibérica oriental y costero catalana meridional. Cuadernos de Geología Ibérica 13, 121-157.

Salas, R., Guimerà, J., Mas, R., Martín-Closas, C., Meléndez, A., Alonso, A. (2001): Evolution of the Mesozoic Central Iberian Rift System and its Cainozoic inversion (Iberian Chain). In: P.A. Ziegler, W. Cavazza, A.F.H. Robertson, S. Crasquin-Soleau (eds.), Peri-Tethys Memoir 6: Peri-Tethyan Rift/Wrench Basins and Passive Margins. Mémoires du Muséum National d'Histoire Naturelle 186, pp.145-185.

Salomon, J. (1982a): El Cretácico inferior de Cameros-Castilla. In: A. García (ed.), El Cretácico de España. Universidad Complutense de Madrid, Madrid, pp. 345-387.

Salomon, J. (1982 b): Les formations continentales du Jurassique Supérieur - Crétacé Inférieur (Espagne du Nord - Chaînes Cantabrique et $N W$ Ibérique). Mémoires Géologiques de l'Université de Dijon 6, Institut des Sciences de la Terre, Dijon, $227 \mathrm{p}$.

Sánchez-Ferrer, F. (1991): Evolución estructural post-Kimmérica de la plataforma continental Vasco-Cantábrica. Unpublished Ph. D. Thesis, Universidad Politécnica de Madrid, Madrid, 173 p.

Schudack, U., Schudack, M. (2009): Ostracod biostratigraphy in the Lower Cretaceous of the Iberian chain (eastern Spain). Journal of Iberian Geology 35, 141-168.

Soler y José, R. (1972): El Jurásico y Cretáceo inferior de Leiza y Tolosa (Cuenca Cantábrica Oriental). Boletín Geológico y Minero 83, 582-594.

Suarez-Gonzalez, P., Quijada, I.E., Mas, J.R., Benito, M.I. (2010): Nuevas aportaciones sobre la influencia marina y la edad de los carbonatos de la Fm Leza en el sector de Préjano (SE de La Rioja). Cretácico Inferior, Cuenca de Cameros. Geogaceta 49, 7-10.

Suarez-Gonzalez, P., Quijada, I.E., Benito, M.I., Mas, R. (2013): Eustatic versus tectonic control in an intraplate rift basin (Leza Fm, Cameros Basin). Chronostratigraphic and paleogeographic implications for the Aptian of Iberia. Journal of Iberian Geology, 39, doi:10.5209/ rev_JIGE.2013.v39.n2.42502

Suarez-Gonzalez, P., Quijada, I.E., Benito, M.I., Mas, R. (2014): Do stromatolites need tides to trap ooids? Insights from a Cretaceous system of coastal-wetlands. In: B. Tessier, J.Y. Reynaud (eds.). International Association of Sedimentologists Special Publication 48, in press.

Tischer, G. (1966): Über die Wealden-Ablagerung und die Tektonik der östlichen Sierra de los Cameros in den nordwestlichen Iberischen Ketten (Spanien). Beihefte zum Geologischen Jahrbuch 44, 123-164.

Warren, J.K. (2006): Evaporites: Sediments, Resources and Hydrocarbons. Springer, Berlin, $1036 \mathrm{p}$.

Warren, J. K. (2010): Evaporites through time: Tectonic, climatic and eustatic controls in marine and nonmarine deposits. Earth-Science 
Reviews 98, 217-268. doi: 10.1016/j.earscirev.2009.11.004

Wells, L. E. and Goman, M. (1995): Late Holocene Environmental Variability in the Upper San Francisco Estuary as Reconstructed from Tidal Marsh Sediments. In: C.M. Isaacs, V.L. Tharp (eds.), Proceedings of the Eleventh Annual Pacific Climate (PACLIM) Workshop. Techni- cal Report of the Interagency Ecological Program for the SacramentoSan Joaquín Estuary 40, pp. 185-198.

Ziegler, P.A. (1988): Evolution of the Arctic-North Atlantic and the Western Tethys. AAPG Memoir 43, 198p. 